\title{
Trace metal enrichment during the Industrial Period recorded across an altitudinal transect in the Southern Central Pyrenees
}

\author{
J.P. Corella ${ }^{\text {a,* }}$, A. Saiz-Lopez a , M.J. Sierra ${ }^{\text {b }}$, M.P. Mata ${ }^{\text {c }}$, R. Millán ${ }^{\text {b }}$, M. Morellón ${ }^{\text {d }}$, C.A. Cuevas a , \\ A. Moreno e,f, B.L. Valero-Garcés e,f \\ a Department of Atmospheric Chemistry and Climate, Institute of Physical Chemistry Rocasolano, CSIC, Serrano 119, 28006 Madrid, Spain \\ b CIEMAT, Department of the Environment (DMA), Avenida Complutense 40, E-28040 Madrid, Spain \\ c Instituto Geológico y Minero de España, Rios Rosas 23, 28003 Madrid, Spain \\ d CITIMAC, University of Cantabria, Faculty of Science, Avenida de los Castros s/n, 39005 Santander, Spain \\ e Pyrenean Institute of Ecology, CSIC, Avda Montañana 1005, 50059 Zaragoza, Spain \\ f Laboratorio Internacional de Cambio Global, CSIC-PUC-UFRJ, Avda Montañana 1005, 50059 Zaragoza, Spain
}

\section{H I G H L I G H T S}

- Significant enrichments of $\mathrm{Hg}, \mathrm{Pb}, \mathrm{Cd}$ and $\mathrm{Zn}$ in NE Spain during the Industrial period

- Site-specific processes and geographical location may affect metals enrichment factors

- High-altitude alpine lakes record more efficiently regional pollution

- Highest trace metal accumulation between 1840 and 1920 CE due to local mining activities

- Secondary increase in anthropogenic trace metals EFs during the Great Acceleration

\section{A R T I C L E I N F O}

\section{Article history:}

Received 5 December 2017

Received in revised form 3 July 2018

Accepted 12 July 2018

Available online 19 July 2018

\section{Keywords:}

Atmospheric pollution

Lakes

Altitudinal gradient

Trace metals

Industrial Period

Pyrenees

\section{G R A P H I C A L A B S T R A C T}

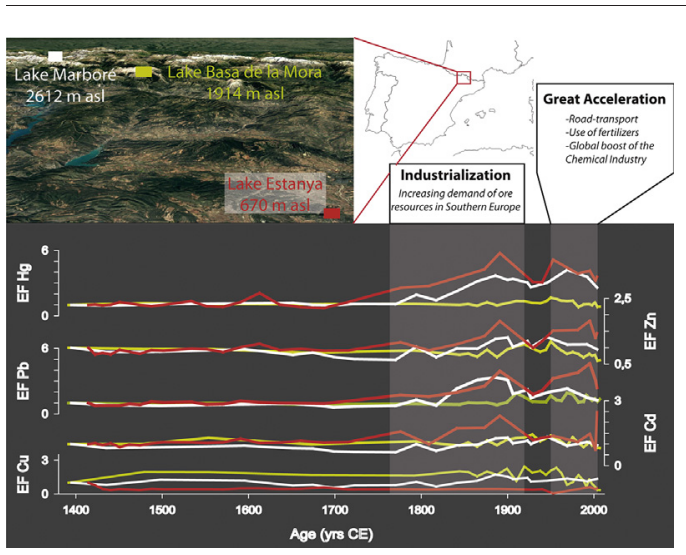

\begin{abstract}
A B S T R A C T
The study of three lacustrine sedimentary archives along an altitudinal transect in the Southern Central Pyrenees - lakes Estanya, Basa and Marboré- has provided a unique record of changes in anthropogenic trace metal concentrations over the last six centuries in NE Iberian Peninsula. Although site-specific processes influence metals enrichments in each lacustrine system, significant enrichments of $\mathrm{Hg}$ and $\mathrm{Pb}$ and minor to moderate enrichments of $\mathrm{Cu}, \mathrm{Cd}$, and $\mathrm{Zn}$ with respect to baseline (Pre-industrial) concentrations highlight intensive release of anthropogenic trace metals with the advent of the Industrial Revolution leading to maximum values during the 20th century. The largest trace metal pollution occurred between 1840s and 1920s CE mainly derived from the increasing demand of ore resources in Southern Europe during the Industrialization. A second, less distinct pollution phase occurred between 1950s and 1990s, associated with the "Great Acceleration" and increased trace metal emissions related to road-transport, use of fertilizers in agriculture and the global boost of the Chemical Industry. Enrichment of mercury during the Industrial Period correlates well with Hg production in Spanish Almadén mines and global emission inventories. Local mining in the Pyrenees and regional smelting activities in Spain and Southern France may explain the enrichment of lead (and associated by-products cadmium and zinc) during the first pollution phase while the use of leaded gasoline since the mid-20th century drives the higher Pb enrichment
\end{abstract}

\footnotetext{
* Corresponding author.

E-mail address: pcorella@iqfr.csic.es (J.P. Corella).
} 
factor found till the late 20th century. This investigation demonstrates that environmental regulations controlling emissions of hazardous metals during the last decades have greatly contributed to a significant reduction of these anthropogenic trace metals enrichments in natural ecosystems although they still double pre-industrial levels. This study also exemplifies the different sensitiveness of lacustrine systems to record past atmospheric pollution phases and highlights the need of multi-archive studies to conduct regional (rather than local) pollution reconstructions.

(c) 2018 Elsevier B.V. All rights reserved.

\section{Introduction}

The atmospheric release of trace metal pollutants is a major problem that threatens living organisms and human population at a global scale. An increasing awareness in the emission trends of mercury, lead and cadmium is developing during the last decades since they are priority contaminants within various international programs aiming at the reduction of environmental and human exposure to air pollution (Pacyna et al., 2009). Although these trace metals are also released to the atmosphere from natural sources (soil and rock dust, natural forest fires, sea spray, volcanism), anthropogenic emissions such as fossil fuel combustion, waste incineration and metallurgy and/or industrial processes are by far the primary pollution source since historical times (Amos et al., 2013, 2015; Martinez-Cortizas et al., 1999; Nriagu, 1996; Gascón-Díez et al., 2017). Mining and smelting activities have been the main anthropogenic sources of atmospheric emissions of trace metals -including $\mathrm{Cu}, \mathrm{Pb}, \mathrm{Hg}, \mathrm{Cd}$ and $\mathrm{Zn}$ - at a global scale (Dudka and Adriano, 1997; Hylander and Meili, 2003). The release of toxic heavy metals during (pre)historic mining and metallurgy activities - particularly since Roman times- also constitute one of the oldest, large-scale anthropogenic impact on the environment (Hillman et al., 2015; Martínez-Cortizas et al., 1997; Nriagu, 1996; West et al., 1997). Nevertheless, it was not until the Industrial Revolution when trace metal releases to the atmosphere became a global concern. Industrialization brought an unprecedented demand for metals and an exponential increase in the intensity of mining, smelting and roasting activities (Nriagu, 1996). As a consequence, the input of these anthropogenic metals into the Earth's surface has greatly exceeded those in the lithosphere (Han et al., 2002).

Unfortunately, atmospheric emission inventories of trace metals are scarce and restricted to the last decades (Horowitz et al., 2014; Nriagu, 1979; Nriagu, 1989; Olendrzyński et al., 1996; Pacyna et al., 2007; Pacyna and Pacyna, 2001; Streets et al., 2017; Zhang et al., 2016). In this line, natural archives have been widely used to reconstruct the long-term pollution history related to human activities to contextualize current atmospheric pollution changes. These sedimentary records also allow us: i) to understand the variability of different pollution sources through time and; ii) to evaluate the different ecosystem's response to enhanced pollution in terms of contaminant's burden and residence time in sediments and soils prior to their release back to the surface environment. This paleoenvironmental information can support policy makers to develop strategies and policies to reduce their emissions and impact in fragile ecosystems.

In the Iberian Peninsula, which has a long tradition of mining and smelting activities since Roman times, primarily focused upon the exploitation of mercury, gold, silver and lead, the anthropogenic release of trace metal to the environment has been continuously preserved in peatbogs (Martinez-Cortizas et al., 1999; Martínez Cortizas et al., 2012), marine and coastal sediments (Leorri et al., 2014; MartínPuertas et al., 2010; Rubio et al., 2000; Serrano et al., 2011) and lacustrine sediments (Camarero et al., 1998; Corella et al., 2017; García-Alix et al., 2013; Hillman et al., 2017; Martín-Puertas et al., 2010). Indeed, mining during Roman times at the Iberian Peninsula and other Roman provinces led to large-scale trace metals atmospheric pollution even recorded in Greenland ice core records (Rosman et al., 1997). Among natural archives, mountain lakes record most efficiently past atmospheric pollution phases since: i) their sediments accumulate continuously and, therefore, the pollution chronicle can be precisely dated using radiometric techniques; ii) the enrichments of trace metals are not overestimated as occurs in peatbogs and/or marine sediments (Biester et al., 2007; Serrano et al., 2011); iii) the "cold trapping" effect caused by elevation that make these locations regional convergence areas of atmospheric pollutants (Camarero, 2017); iv) their location in remote areas that may not be greatly affected by local activities thus recording the long-range transport of atmospheric pollutants (Bacardit et al., 2012; Camarero et al., 2009; Catalan, 2015; Thevenon et al., 2011) and v) their reduced catchments make them more sensitive to direct atmospheric deposition of pollutants. Nevertheless, trace metal's biogeochemical cycles are intrinsic to each individual alpine lake. Therefore, a site-specific detailed understanding of trace metal depositional processes should be achieved before using these natural archives as proxies for past regional atmospheric pollution.

The main objective of this study is to evaluate the anthropogenic trace metal enrichment and depositional patterns in the Southern Central Pyrenees since the onset of the Industrial Period. In this aim, a comparative study has been undertaken in three contrasting lacustrine environments across an altitudinal gradient from Lake Estanya (located in the lowland close to the Ebro Basin) and the alpine lakes Basa de la Mora and Marboré, located in high-elevation areas of the South Central Pyrenees. The trace metal distribution in each lake, as well as the intercomparison of the different metal concentration and enrichments among the studied lakes allow us: i) to understand the different lake's ability to preserve the pollution signal according to their intrinsic limnological and morphometric characteristics; ii) to reconstruct the atmospheric contamination in the Southern Pyrenees for the last six centuries and iii) to elucidate possible sources controlling the enrichment of the anthropogenic trace metals $(\mathrm{Cu}, \mathrm{Cd}, \mathrm{Hg}, \mathrm{Zn}$ and $\mathrm{Pb})$ at a local Vs regional scale.

\section{Study site}

The three studied lakes are located in a N-S altitudinal transect - Lake Estanya (LE), $670 \mathrm{~m}$ a.sl; Lake Basa de la Mora (LB), $1914 \mathrm{~m}$ a.s.l. and Lake Marboré (LM); 2612 m a.s.l.; Fig. 1, across the Southern Central Pyrenees. The area is characterized by south verging thrust and folds, mainly composed of Mesozoic and Early Cenozoic rocks (Vera, 2004). LM and LB are located in the Inner Mountain Range while LE is located in the Southern External Ranges, close to the northern boundary of the Ebro River Basin. The three lakes have relatively small lake's surface area (ranging from 5.5 to $18.8 \mathrm{ha}$ ) and small to middle sized watersheds (ranging from 106 to 462 ha) composed mostly of carbonated bedrock (Leunda et al., 2017; Morellón et al., 2009a; Oliva-Urcia et al., 2018; Pérez-Sanz et al., 2014; Valero-Garcés et al., 2013).

The Southern Central Pyrenees are located in a transitional area between the Eurosiberian and Mediterranean bioclimatic regions (Peinado Lorca and Rivas-Martínez, 1987) which are mainly different in terms of precipitation amount and seasonality. Mean annual temperatures and precipitation across the altitudinal gradient ranges from $\sim 5$ ${ }^{\circ} \mathrm{C}$ and $2000 \mathrm{~mm}$ close to LM to $14{ }^{\circ} \mathrm{C}$ and $470 \mathrm{~mm}$ in LE (Morellón et al., 2009b). The elevational gradient across the three lakes results in an altitudinal distribution of vegetation where lowlands are occupied by crops and riparian corridors while forest composed of Pinus unciata 


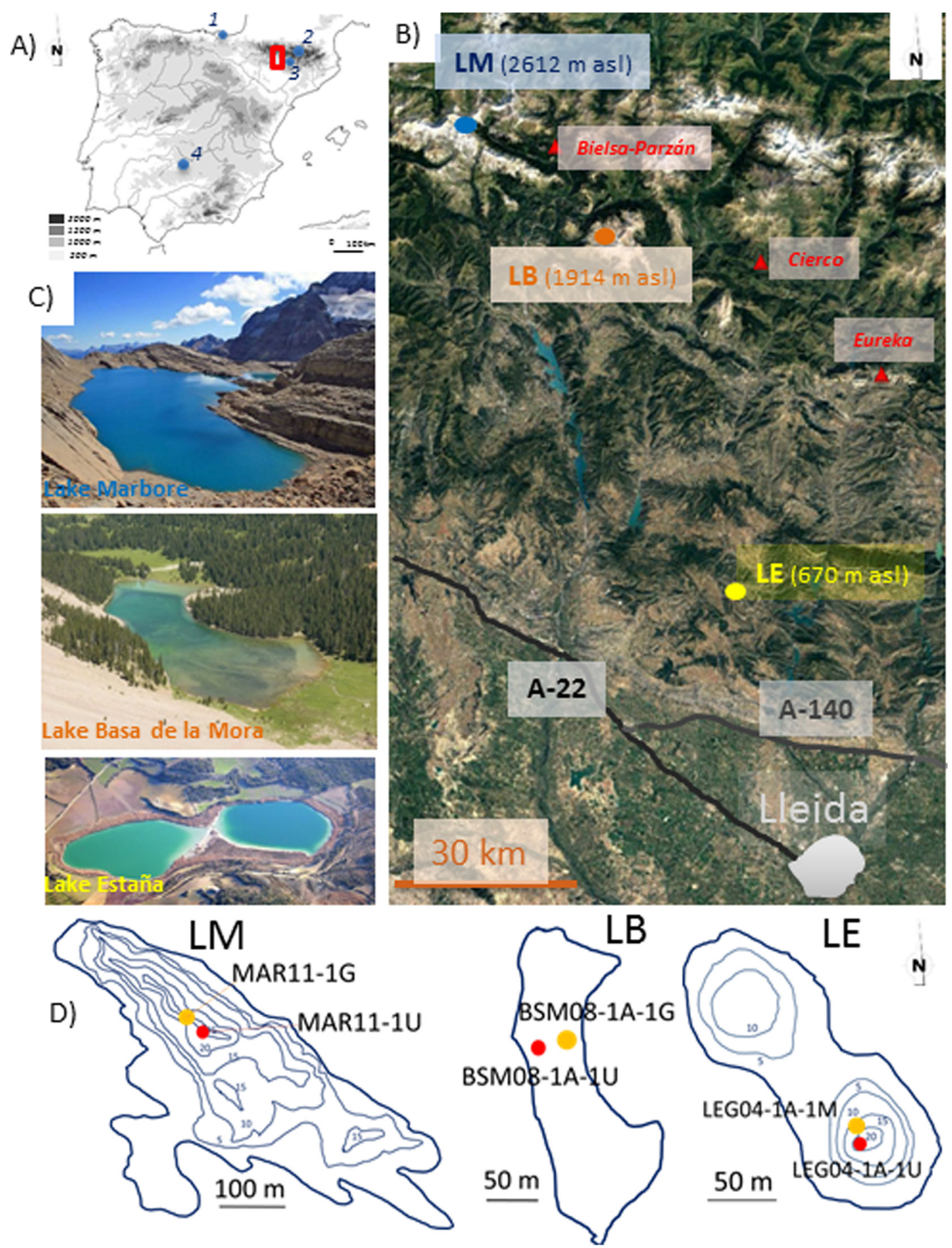

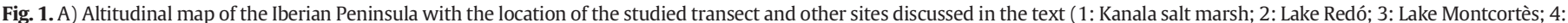

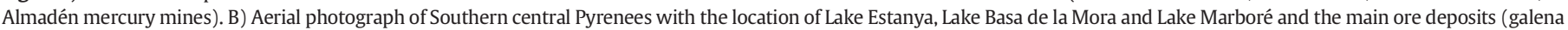

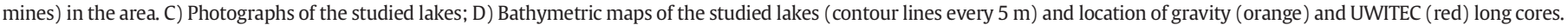

mixed with Juniperus communis and shrublands occur at the base of the foothills up to $2000 \mathrm{~m}$ a.s.l. where the tree line is located (GonzálezSampériz et al., 2017; Pérez-Sanz et al., 2014).

$\mathrm{LM}\left(42^{\circ} 41^{\prime} \mathrm{N} ; 0^{\circ} 2^{\prime} \mathrm{E}\right.$, Fig. 1$)$ has a surface area of 14.3 ha and a watershed of 137 ha (Valero-Garcés et al., 2013). It is emplaced in CretaceousNeogene carbonated limolites (Nicolás-Martínez, 2013). The vegetation cover around the lake is very scarce with only a few remains of alpine rocky species (Leunda et al., 2017; Sánchez-España et al., 2018). The lake has a maximum depth of $30 \mathrm{~m}$ (Fig. 1D). The lake level is controlled mostly by precipitation/evaporation balance with an inlet and an outlet located in the western and southern area of the lake respectively (Nicolás-Martínez, 2013; Valero-Garcés et al., 2013). It is a cold dimictic and ultra-oligotrophic lake with alkaline waters (Sánchez-España et al., 2018). Ice and snow cover LM surface from December to July (SánchezEspaña et al., 2018).

LB $\left(42^{\circ} 32^{\prime} \mathrm{N}, 0^{\circ} 19^{\prime} \mathrm{E}\right.$, Fig. 1$)$ has a surface area of 5.5 ha and a watershed of 462 ha (Pérez-Sanz et al., 2014; Valero-Garcés et al., 2014). The watershed is composed of Mesozoic limestones and Triassic 
hypovolcanic rocks (ophites) (Pérez-Sanz et al., 2014). It is a holomictic lake with maximum water depths varying seasonally from 2.5 to $4.5 \mathrm{~m}$ depth (Fig. 1D). The lake level is controlled by precipitation and surface run-off with ephemeral inlets in the southern shore and a surface outlet in the southern lake margin. The watershed is mainly vegetated with alpine grassland, Pinus uncinata forest and shrublands.

$\operatorname{LE}\left(42^{\circ} 02^{\prime} \mathrm{N}, 0^{\circ} 32^{\prime} \mathrm{E}\right.$, Fig. 1$)$ has a surface area of 18.83 ha and a watershed of 106 ha (Morellón et al., 2009b; Valero-Garcés et al., 2014). The endorheic watershed basin is constituted by Triassic marls and claystones (in the lake basin) and carbonated rocks in the highest elevations of the catchment (Morellón et al., 2011). It is a monomictic and oligotrophic lake with a maximum lake's water depth of $20 \mathrm{~m}$ (Fig. 1D). The hydrological balance is mainly controlled by groundwater input and evaporation output (Morellón et al., 2009a). Vegetation in the watershed consists in scrublands and oak forests in the high elevated areas and a patchy landscape of natural vegetation and cereal crops in the lowlands (González-Sampériz et al., 2017).

Lake sediments for the last six centuries in the three studied lakes consist on massive to laminated siliciclastic mud with variable organic (TOC ranging in LM from 0.1 to $1.1 \%$; in LB from 1.5 to $2 \%$; and in LE from 2.4 to $8 \%$ ) and carbonate contents (20-95\%) (Valero-Garcés et al., 2014).

\section{Material and methods}

\subsection{Sediment coring}

Sediment cores were retrieved in the studied sites using an UWITEC (MAR11-1U, BAS08-1A-1U) and Kullemberg (LEG04-1K-1) floating platforms from IPE-CSIC and Limnological Research Center (LRC), University of Minnesota, respectively. UWITEC gravity cores were additionally collected to preserve the upper sediments and the water-sediment interphase (MAR11-1G-1U, BAS08-1A-1G, LEG1A-1M). All the cores were retrieved from the deepest part of the lakes (LE, $24 \mathrm{~m}$ depth, LM, $27 \mathrm{~m}$ water depth, LB, $2.5 \mathrm{~m}$ depth) (Fig. 1D).

\subsection{Age-depth models}

The age-depth models in the three lakes for the last 600 years are based on ${ }^{137} \mathrm{Cs}$, ${ }^{210} \mathrm{~Pb}$ and Accelerator Mass Spectrometry (AMS) ${ }^{14} \mathrm{C}$ radiometric dating techniques (Fig. 2). These chronologies have been already stablished in previous studies - Lake Estanya (Morellón et al., 2011); Lake Basa de la Mora (Pérez-Sanz et al., 2014); Lake Marboré (Leunda et al., 2017; Oliva-Urcia et al., 2018). In the three studied sequences ${ }^{210} \mathrm{~Pb}$ dating was obtained by gamma ray spectrometry. Excess (unsupported) ${ }^{210} \mathrm{~Pb}$ was calculated by the difference between total ${ }^{210} \mathrm{~Pb}$ and ${ }^{214} \mathrm{~Pb}$ for individual core intervals. ${ }^{210} \mathrm{Pbdates}$ in the three sedimentary sequences were determined using the constant rate of supply (CRS) model. The age-depth models in the three lake records have been constructed by linear interpolation between the median ages of the probability distribution of adjacent calibrated dates.

The chronology for the LM sediment sequence was developed using one AMS ${ }^{14} \mathrm{C}$ date from the long core MAR11-1U and ${ }^{137} \mathrm{Cs}$ and ${ }^{210} \mathrm{~Pb}$ dating performed in the gravity core MAR11-1G-1U. The ${ }^{210} \mathrm{~Pb}$ age model is supported by the presence of a ${ }^{137} \mathrm{Cs}$ peak at $6 \mathrm{~cm}$ (1963 CE) in agreement with the ${ }^{210} \mathrm{~Pb}$ chronology (Oliva-Urcia et al., 2018; Leunda et al., 2017). In LM the upper $41 \mathrm{~cm}$ comprises the period 1400-2010 Common Era (henceforth all dates are in CE) with mean sedimentation rates (SR) of $0.7 \mathrm{~mm} / \mathrm{yr}$.

The chronology for the LE sediment sequence was achieved by combining two ${ }^{14} \mathrm{C}$ dates in core LEG04-1K-1 and ${ }^{137} \mathrm{Cs}$ and ${ }^{210} \mathrm{~Pb}$ dating in core LEG1A-1M. The ${ }^{210} \mathrm{~Pb}$ chronology matches closely ages for the profile derived using ${ }^{137} \mathrm{Cs}$ since two clear ${ }^{137} \mathrm{Cs}$ peaks at $14-15 \mathrm{~cm}$ and 8-9 cm, are consistent with ${ }^{210} \mathrm{~Pb}$ dates of $1960-1964 \mathrm{CE}$ and 1986-1990 CE respectively (Fig. 2) (Morellón et al., 2011). LE shows SR of $0.87 \mathrm{~mm} / \mathrm{yr}$ for the period $1400-1965 \mathrm{CE}(67-14 \mathrm{~cm})$. SR

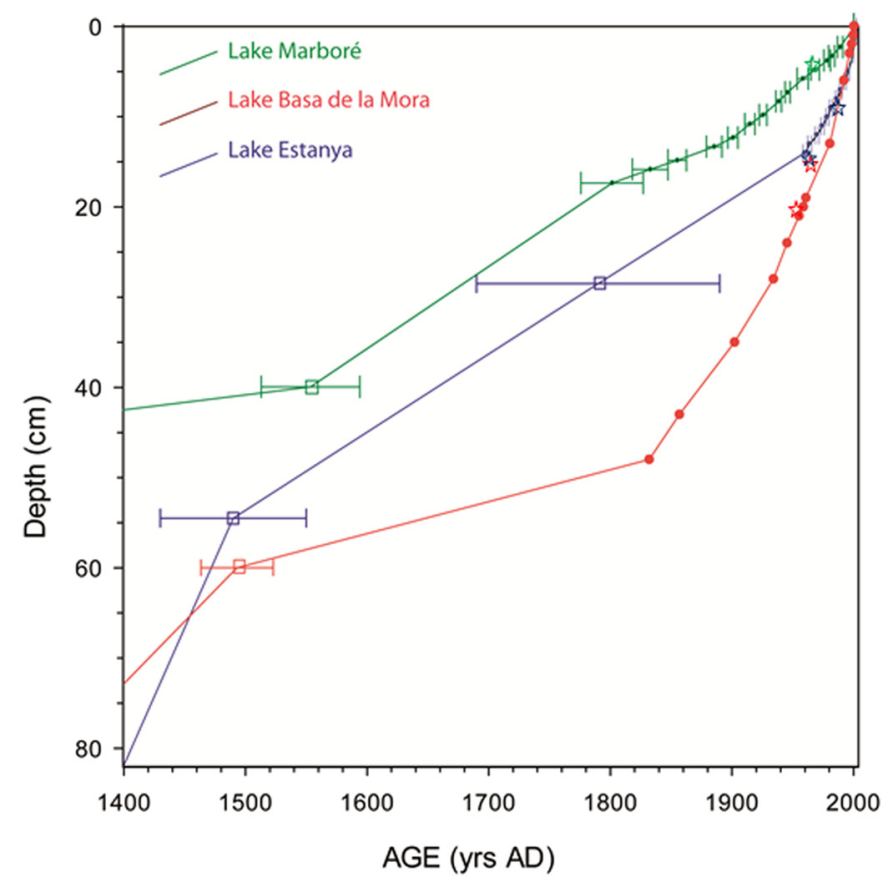

Fig. 2. Age-depth models for the three studied lakes based on ${ }^{210} \mathrm{~Pb}$ (circles), ${ }^{137} \mathrm{Cs}$ (stars) and ${ }^{14} \mathrm{C}$ (squares) radiometric dating (modified from Morellón et al., 2011; Pérez-Sanz et al., 2014 and Leunda et al., 2017).

increased up to $3.41 \mathrm{~mm} / \mathrm{yr}$ in LE since $1965(14-0 \mathrm{~cm})$ due to higher clastic input to the lake.

LB age-depth model is constrained by one AMS ${ }^{14} \mathrm{C}$ dates in core BAS08-1A-1U and ${ }^{137} \mathrm{Cs}$ and ${ }^{210} \mathrm{~Pb}$ dating in core BAS08-1A-1G. Two ${ }^{137} \mathrm{Cs}$ peaks were recorded at $15 \mathrm{~cm}$ and $21 \mathrm{~cm}$ depth providing markers for the 1954-1959 and the 1963 maximum atmospheric nuclear bomb testing in agreement with ${ }^{210} \mathrm{~Pb}$ chronology (Pérez-Sanz et al., 2014). LB displays mean SR of $1.2 \mathrm{~mm} / \mathrm{yr}$ for the period $1400-2011 \mathrm{CE}(73-0 \mathrm{~cm})$ (see Morellón et al., 2011; Pérez-Sanz et al., 2014, Oliva-Urcia et al., 2018 and Leunda et al., 2017 for further descriptions and information of the age-depth models in the studied lakes).

\subsection{Geochemical analyses}

The sediment cores were split lengthwise. Geochemical analyses were carried out in discrete samples retrieved downcore in the studied cores at mean intervals of $1-2 \mathrm{~cm}$ (Fig. 3 and Fig. S1). In order to determine the concentration of major inorganic elements including ( $\mathrm{Al}, \mathrm{As}$, $\mathrm{Ba}, \mathrm{Cd}, \mathrm{Co}, \mathrm{Cr}, \mathrm{Cu}, \mathrm{Fe}, \mathrm{K}, \mathrm{Mg}$, Mo, Ni, Pb, Si, Sr, Zn, and $\mathrm{Zr}$ ), 81 samples were digested with $\mathrm{HNO}_{3}(9 \mathrm{ml})$ and $\mathrm{HCl}(3 \mathrm{ml})$ in a microwave oven 'BERGHOF MWS' and analyzed by optical emission spectrometry using inductively coupled plasma - atomic emission spectroscopy (ICP-OES; Thermo ICP-OES iCAP 6300 DUO - Thermo Fisher Scientific, Waltham, MA, USA) at the IPE-CSIC laboratories. Total Carbon (TC), Total Organic Carbon (TOC) and Total Inorganic Carbon (TIC) had been previously determined with a LECO SC 144 DR elemental analyzer (Morellón et al., 2011; Oliva-Urcia et al., 2018; Pérez-Sanz et al., 2014). TIC values were obtained by subtracting TOC from TC. Total Hg concentration measurements were carried out by Cold Vapor Atomic Absorption Spectrophotometry (CV-AAS) using an Advance Mercury Analyzer (AMA 254, LECO Company). This equipment is specifically designated for the direct mercury determination in solid and liquid samples without a need of sample chemical pre-treatment. Certified reference materials (CRM) were used to determine the accuracy and precision of the Hg measurements. These reference materials were ZC73027 (rice, $4.8 \pm 0.8$ $\mu \mathrm{kg}^{-1}$ ) and CRM051-050 (Clay soil, $4.08 \pm 0.09 \mathrm{mg} \mathrm{kg}^{-1}$ ). The repeatability was $S_{r} \leq 15 \%$ and the relative uncertainty associated with the 


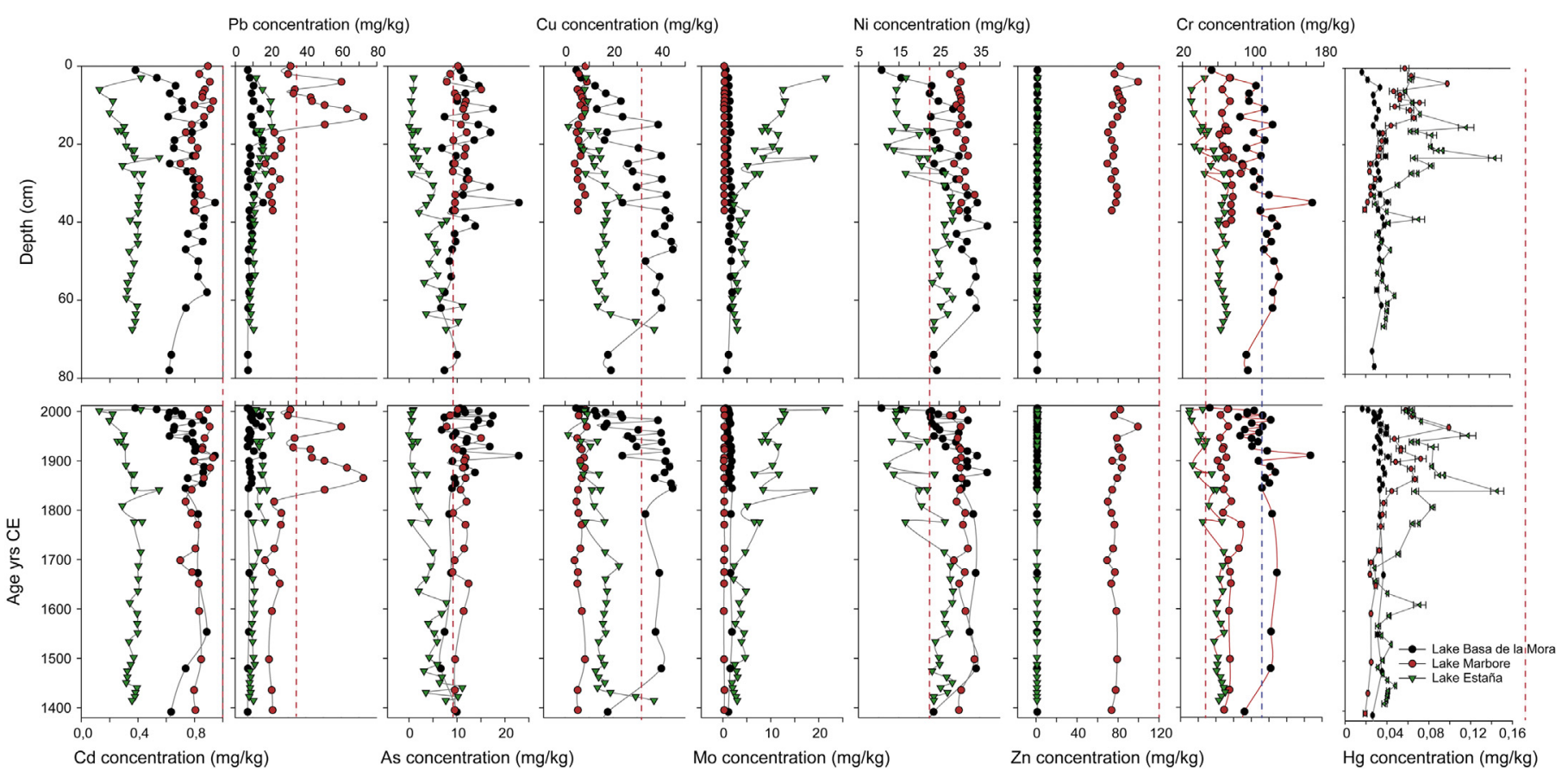

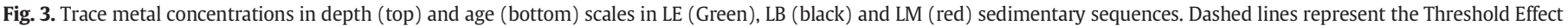
Concentrations (TEC, red) and the Severe Effect Level (SEL, black) values in dry sediment for Pb, As, Cu, Ni, Cr and $\mathrm{Hg}$ according to MacDonald et al. (2000).

method $(\mathrm{k}=2)$ was $\pm 20 \%$. All analyses were run at least in triplicate. Total metal concentrations are expressed in $\mu \mathrm{g} \mathrm{g}^{-1}$ of dry weight sediment. In this study, EFs have been estimated to identify human interference in natural element cycles. Firstly all the anthropogenic trace metals have been normalized to aluminum $(\mathrm{Al})$ in order to confirm that the changes in metals concentrations are not related to detrital input variability. Al has been selected for normalization since this lithogenic element is immobile (i.e. geochemically stable) in the sediments and it is abundant in carbonated watersheds (Boës et al., 2011; Tylmann, 2005). EFs have been calculated using the basal sediments average concentrations that represent baseline conditions.

$E F=\frac{\left[M_{c m}\right] /\left[A_{c m}\right]}{\left[M_{\text {bottom }]} /\left[A l_{\text {bottom }]}\right.\right.}$

where $\left[\mathrm{M}_{\mathrm{cm}}\right]$ and $\left[\mathrm{Al}_{\mathrm{cm}}\right]$ represent the metal and aluminum concentrations at the same depths of the sediment cores while $\left[\mathrm{M}_{\text {bottom }}\right]$ and $\left[\mathrm{Al}_{\text {bottom }}\right]$ are the metal and aluminum concentrations in the basal sediments of the sediment cores in LB, LM and LE respectively. It is important to note that baseline conditions in the 15th century do not indicate natural background conditions since anthropogenic activities have intermittently occurred since Roman times.

In $\mathrm{LM}, 12$ samples were collected for $\mathrm{Pb}$ isotopic analyses since $\mathrm{Pb}$ total concentrations show the highest values in this lake's record (Fig. 3, Table S1). A $0.1 \mathrm{~g}$ of powdered rock was digested overnight in HNO3 and evaporated to dryness. The residue is taken in $\mathrm{HBr}$, and $\mathrm{Pb}$ isolated by conventional ion-exchange chromatography (AG1-X8 resin in $\mathrm{HBr}$ and $\mathrm{HCl}$ media). The recovered lead is evaporated to dryness, dissolved in $0.32 \mathrm{M} \mathrm{HNO}_{3}$ and diluted to a final concentration of 150-200 ppb. Lead isotope ratios are measured with a ThermoNEPTUNE multicollector ICP-MS from the University of Basque Country, and the mass fractionation is internally corrected after the addition of thallium isotopic reference material NBS-997. Detailed protocols are similar to those described by (Chernyshev et al., 2007).

\subsection{Statistical analysis}

Statistical correlations between all the geochemical elements ( $\mathrm{Al}, \mathrm{As}$, $\mathrm{Ba}, \mathrm{Cd}, \mathrm{Co}, \mathrm{Cr}, \mathrm{Cu}, \mathrm{Fe}, \mathrm{Hg}, \mathrm{K}, \mathrm{Mg}, \mathrm{Mo}, \mathrm{Ni}, \mathrm{Pb}, \mathrm{Si}, \mathrm{Sr}$, TIC, TOC, Zn, and Zr) and between TIC and trace metals EFs have been carried out to understand the main environmental and depositional processes that occur in the three studied lakes. The data are not normally distributed; therefore, correlation coefficients were calculated using the Spearman rank order method (Tables S2 and S3). Statistical analyses have been performed using the SPSS 23.0 software.

\section{Results and discussion}

\subsection{Trace element geochemical trends in the sediment cores}

Concentration for most of the trace metals in the three studied lakes followed different down-core concentration evolutions (Table S4, Fig. 3). During the Pre-industrial Period LM exhibited higher concentrations of $\mathrm{Cd}, \mathrm{Pb}, \mathrm{As}$, Ni and $\mathrm{Zn}\left(0.8,20.8,10.3,30.9\right.$ and $75.4 \mathrm{mg} \mathrm{kg}^{-1}$ respectively). Zn concentrations are anomaly high in LM before the preIndustrial Period compared to LB and LE suggesting local sources, most likely due to weathering of sphalerite outcropping in the lake's watershed. Indeed, a recent limnological survey in the lake's waters showed very high $\mathrm{Zn}$ concentrations in the water column, likely associated to that weathering process (Sánchez-España et al., 2018). Maximum concentrations of $\mathrm{Cr}\left(112 \mathrm{mg} \mathrm{kg}^{-1}\right)$ and $\mathrm{Cu}\left(30.8 \mathrm{mg} \mathrm{kg}^{-1}\right)$ were found in LB. On the other hand, LE showed the highest concentrations of Mo (3.2 $\mathrm{mg} \mathrm{kg}^{-1}$ ) and $\mathrm{Hg}\left(0.04 \mathrm{mg} \mathrm{kg}^{-1}\right)$. A noticeable increase of some trace metals occurred in LE and LM since the Industrial Period, with a two to three-fold increase in $\mathrm{Hg}$ and $\mathrm{Pb}$ concentrations in $\mathrm{LE}$ and $\mathrm{LM}$ and a 3-fold increase in Mo in LE (Table S4). LB concentrations of As$\mathrm{Cu}-\mathrm{Ni}-\mathrm{Cr}$ largely exceed the Threshold Effect Concentration (TEC) guideline implying that adverse effects in the lacustrine ecosystem might have occurred (MacDonald et al., 2000). Concentrations of PbAs-Ni-Cr, As-Cu-Ni-Cr and Ni-Cr exceed the Threshold Effect Concentration guideline (TEC, MacDonald et al., 2000) in LM, LB and LE, 


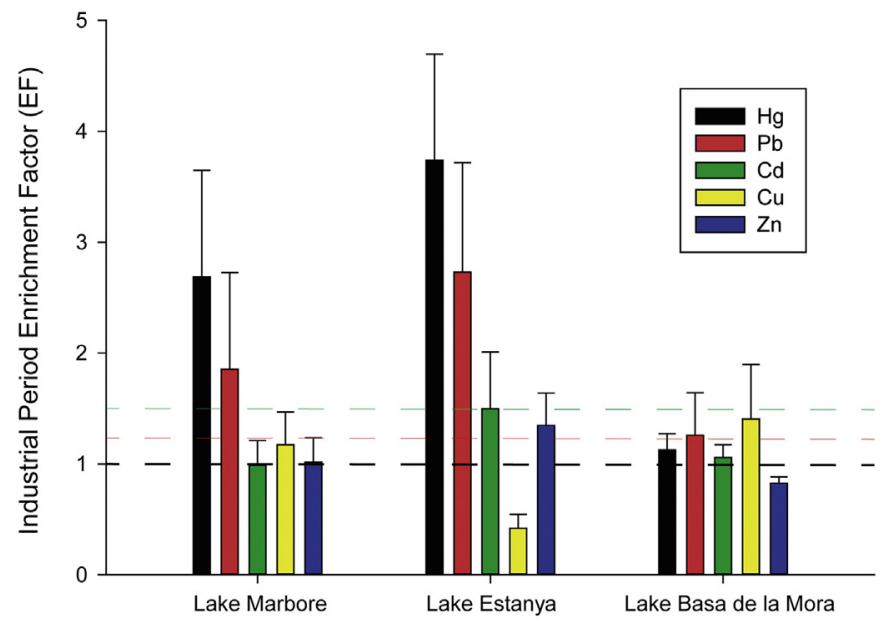

Fig. 4. Anthropogenic trace metals average enrichment factors in LM; LE and LB and standard deviations during the Industrial Period with respect to baseline levels (before $1760 \mathrm{CE}$ ). Black, red and green dashed lines represent EF thresholds for minor $(<1.2)$, moderate $(<1.5)$ and major $(1.5 \geq)$ enrichments respectively.

respectively (Fig. 3), suggesting that these trace metal concentrations might have had ecotoxicological relevance in these lacustrine ecosystems.

\subsubsection{Trace metals’ enrichment factors}

This study focus on the non-crustal origin of trace metals enrichment during the last centuries. Thus, positive enrichment factors (EFs) for the
Industrial Period were found for $\mathrm{Hg}$, $\mathrm{Pb}$, and, to a lesser extent, for $\mathrm{Zn}, \mathrm{Cd}$ and $\mathrm{Cu}$, thereby indicating their polluting character (Table S4, Figs. 4, 5 and 6). EFs of these trace metals are in agreement with trace metals EFs in other alpine regions in Europe that accounts for higher enrichment of $\mathrm{Pb}, \mathrm{Hg}$ and $\mathrm{As}$ and, secondarily, $\mathrm{Zn}, \mathrm{Cd}$ and $\mathrm{Cu}$ (Camarero, 2017; Camarero et al., 2009). Arsenic does not show any particular enrichment in our study sites because the likely anthropogenic signal is masked by the high concentrations of As in Pyrenean natural (pre-industrial) soils (Bacardit and Camarero, 2010b; Camarero, 2003; Camarero et al., 2009). $\mathrm{Pb}, \mathrm{Zn}, \mathrm{Cd}$ and $\mathrm{Cu}$ EFs show a large variability in each lacustrine system. In $\mathrm{LM}, \mathrm{Hg}$ and $\mathrm{Pb}$ exhibit the major EFs (2.7 and 1.8 respectively) while $\mathrm{Cu}$ EF (1.2) showed minor increases. $\mathrm{Mo}, \mathrm{Hg}$ and $\mathrm{Pb}$ showed the highest EFs in LE (6.9, 3.7 and 2.7 respectively). Moderate EFs in this lake also occur for $\mathrm{Cd}$ (1.5) and $\mathrm{Zn}$ (1.4). Trace metals EFs in these two lakes could be clustered in two main periods (1840s-1920s CE) and (1950s-1990s CE). On the other hand, LB do not follow the same trend observed in LM and LE, showing only a moderate increase of $\mathrm{Cu}$ (1.4) and $\mathrm{Pb}$ (1.3), and minor increases of $\mathrm{Hg}$ (1.1).

\subsection{2. $\mathrm{Pb}$ isotope record in Lake Marboré}

The different $\mathrm{Pb}$ isotopic dataset (Table $\mathrm{S} 1$ ) correlates well suggesting a binary mixing model with two components ( $\mathrm{Pb}$ geogenic and $\mathrm{Pb}$ anthropogenic) (Figs. 6 and 7, Fig. S1). According to this overall correlation, trends in ${ }^{208} \mathrm{~Pb} /{ }^{206} \mathrm{~Pb}$ and ${ }^{207} \mathrm{~Pb} /{ }^{206} \mathrm{~Pb}$ (Fig. 6) are representative of all isotope ratios summarized in Table $\mathrm{S} 1 .{ }^{208} \mathrm{~Pb} /{ }^{206} \mathrm{~Pb}$ and ${ }^{207} \mathrm{~Pb} /{ }^{206} \mathrm{~Pb}$ ratios show low (geogenic) values during for the period ca. 1500-1750 CE and a progressive increase since industrialization. The highest (anthropogenic) isotopic ratios are found at the turn of the 20th century and during the Great Acceleration (i.e. since 1950s CE) while a return towards less radiogenic values occurred at 1930 and during the last decade.

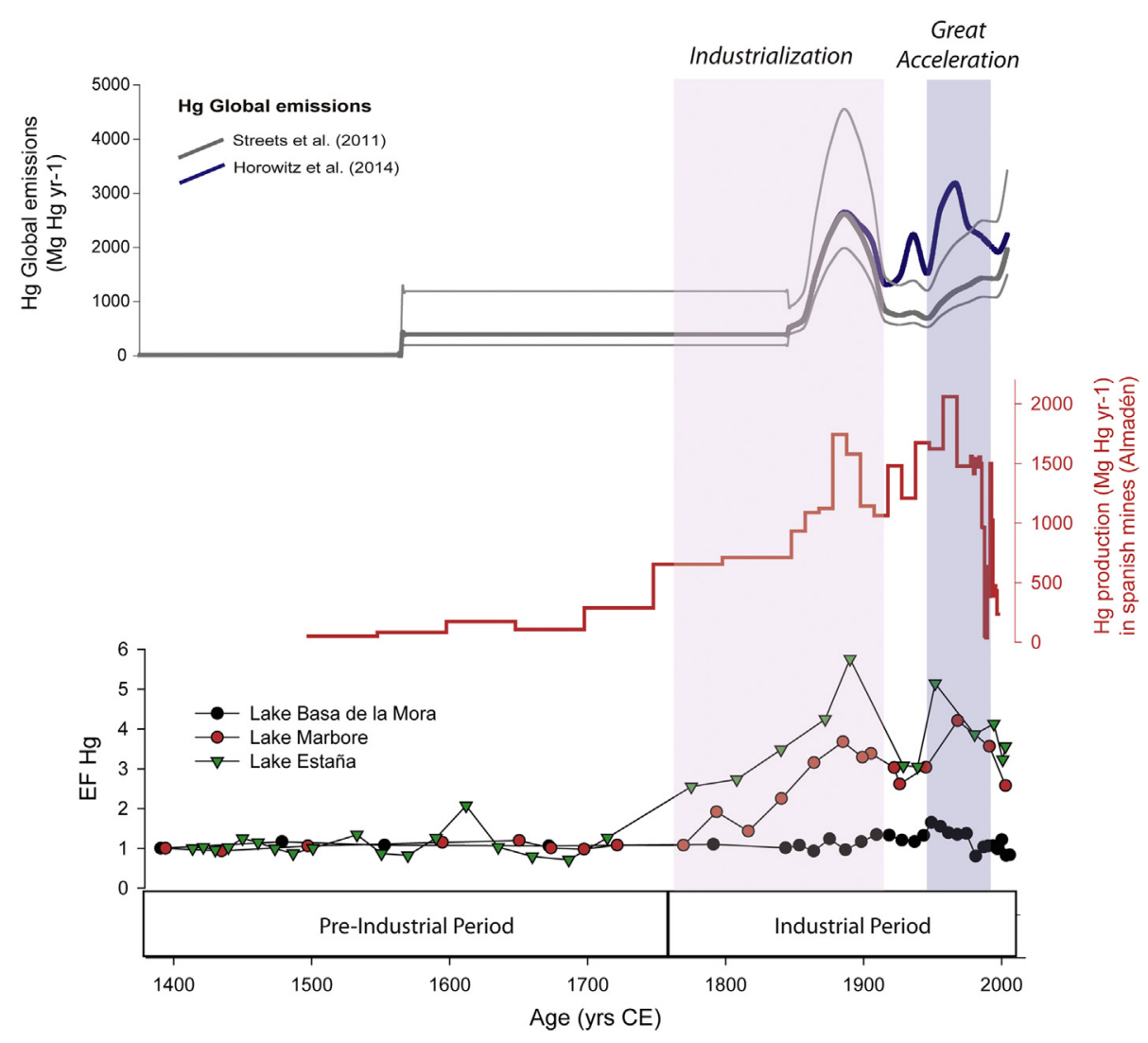

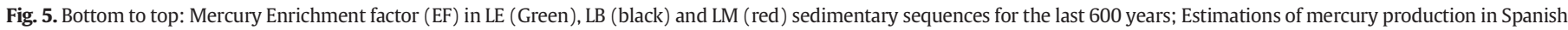
mines (after Hylander and Meili, 2003); Global primary anthropogenic mercury emissions to the atmosphere (from Streets et al., 2011; Horowitz et al., 2014). 


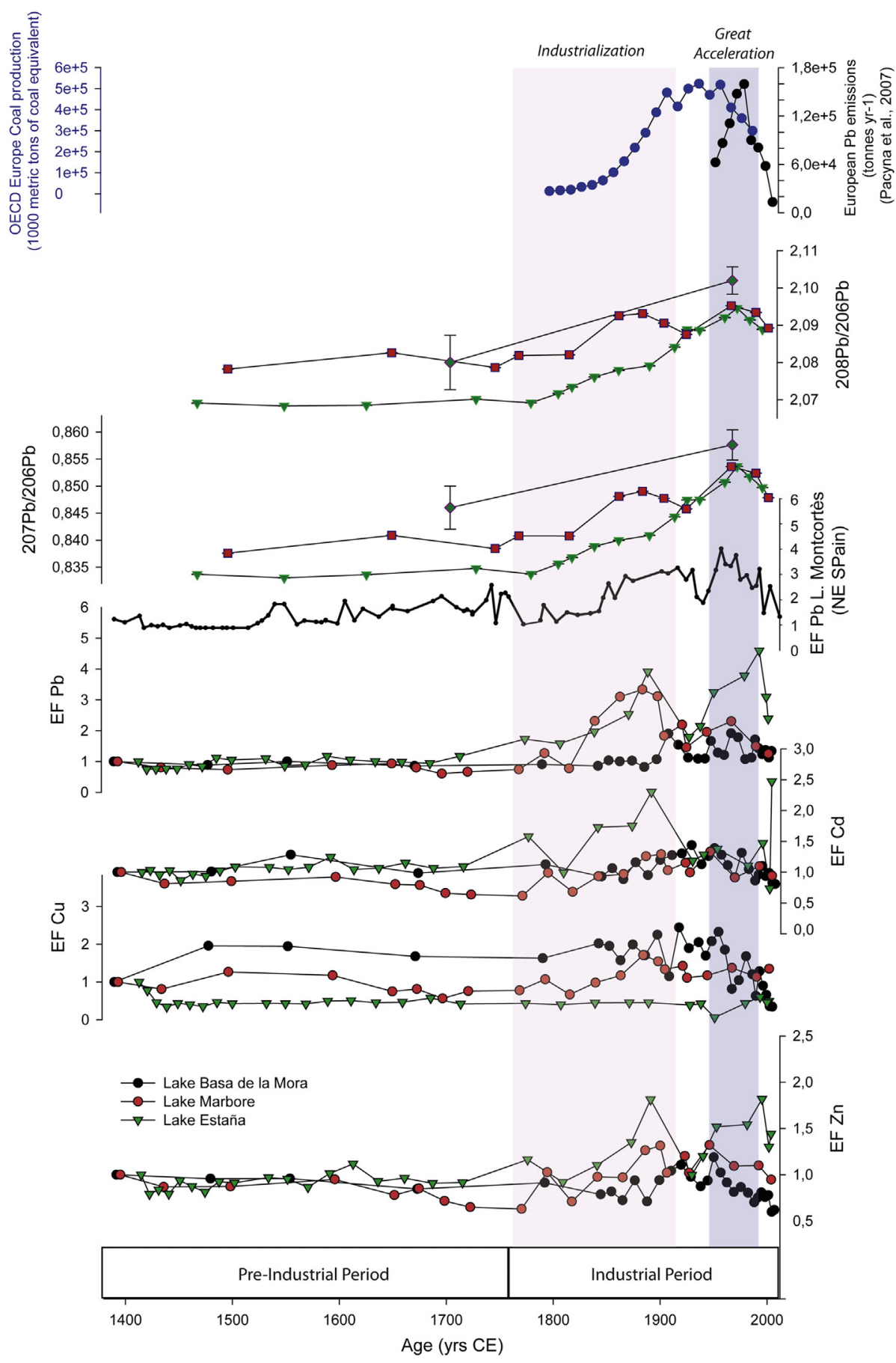

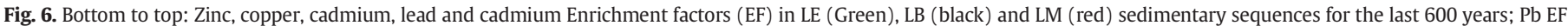

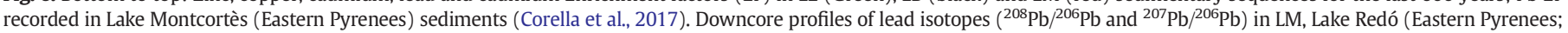

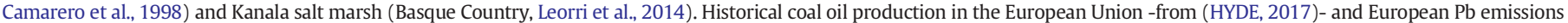
inventory (Pacyna et al., 2007).

\subsection{Depositional and environmental controls of anthropogenic trace metal across the Southern Pyrenees lacustrine systems}

The trace metal record preserved in LB, LE, and LM show a significant variability in terms of concentration, EFs and statistical correlations with other geochemical elements (Tables S2, S3 and S4) that may reflect different sources, transport pathways and depositional and preservation mechanisms operating across the Southern Central Pyrenees altitudinal gradient. Mean trace metal concentration values differ in each site during the Pre-Industrial Period for the three lakes (Fig. 3). These differences may respond to i) the different lithological variability in the lake's watersheds that ultimately affects the metals entering the lake via run-off and; ii) the sensitivity of the depositional system to record and preserve the trace metals in the sediments.

LM main anthropogenic pollutants $\mathrm{Hg}, \mathrm{Pb}, \mathrm{Cd}, \mathrm{Zn}$ do not correlate with the main lithogenic elements ( $\mathrm{Al}, \mathrm{Ti}, \mathrm{K}, \mathrm{Mg}, \mathrm{Ba}$ and $\mathrm{Zr}$ ) (Table S2) that reach the basin via run-off. Therefore, direct atmospheric deposition is the most likely processes governing the accumulation of these trace metals in LM. Trace metal enrichments in LM does neither correlate with: i) the organic matter content (TOC) implying that trace 

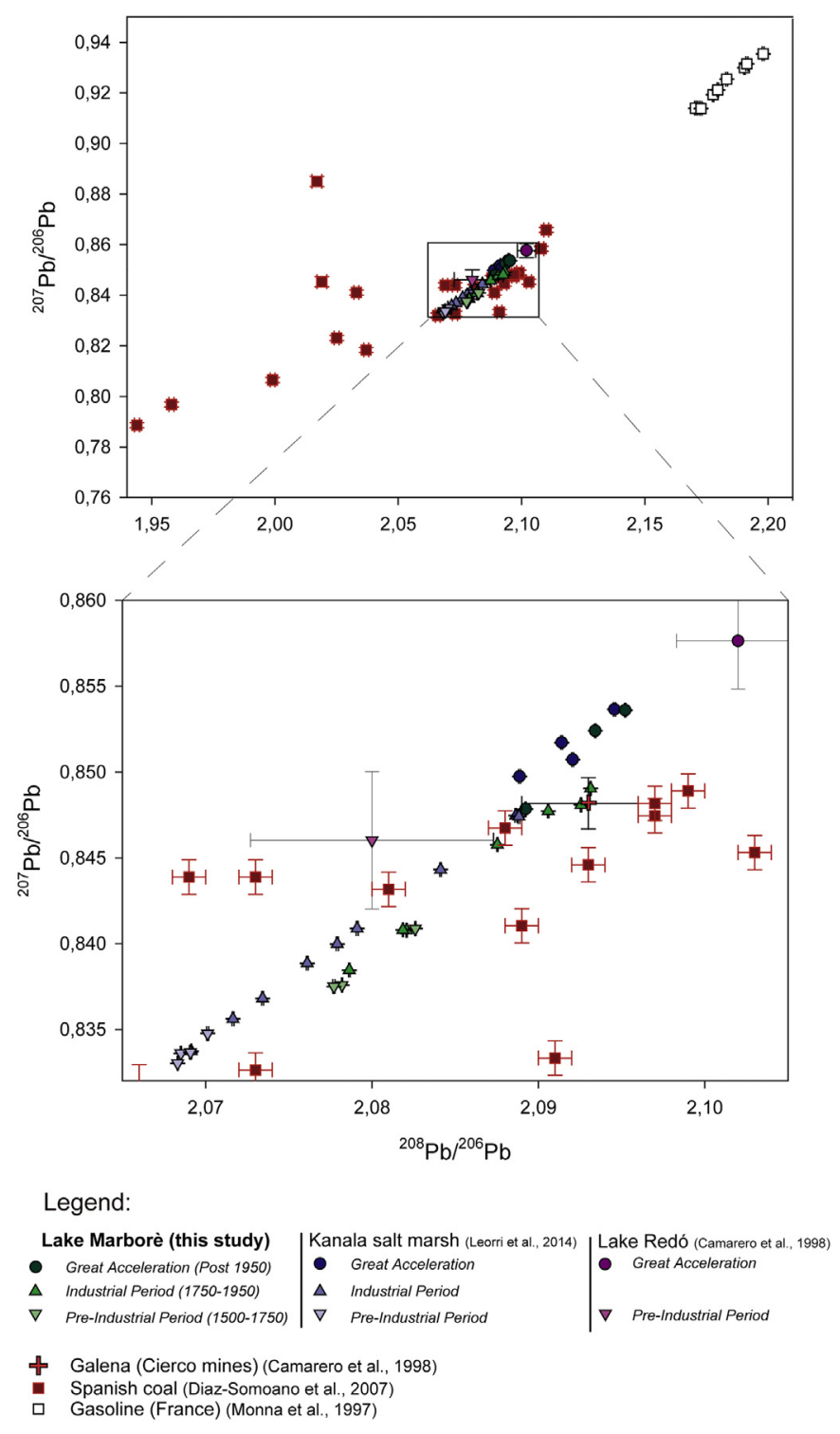

Fig. 7. $\mathrm{Pb}$ isotope ratio diagram between ${ }^{208} \mathrm{~Pb} /{ }^{206} \mathrm{~Pb}$ and ${ }^{207} \mathrm{~Pb} /{ }^{206} \mathrm{~Pb}$ from Lake Marboré (Green), Lake Redó (Purple) (Camarero et al., 1998) and Kanala salt marsh (blue) (Leorri et al., 2014) during the Pre-Industrial and Industrial Periods and during the Great Acceleration. The ${ }^{208} \mathrm{~Pb} /{ }^{206} \mathrm{~Pb}$ and ${ }^{207} \mathrm{~Pb} /{ }^{206} \mathrm{~Pb}$ isotope ratio of galena samples from Pyrenean Cierco mines and inventories from Spanish coal and French gasoline are also shown.

metals fixation in the sediment is not controlled by the very reduced biological activity in LM waters (Sánchez-España et al., 2018), nor with ii) Total Inorganic Carbon content (TIC) (Table S2, S4) suggesting that trace elements deposition is not mediated by carbonate precipitation. Indeed, LM sediments are mostly devoid of carbonate and the small carbonate fraction is clastic, transported from the glaciated sediments in the watershed. The water column is undersaturated with respect to calcite (Sánchez-España et al., 2018; Oliva-Urcia et al., 2018) and small calcite particles that may form seasonally in the lake dissolve before depositing in the lake bottom without trapping trace metals.

Weak correlations of $\mathrm{Hg}, \mathrm{Pb}$ and $\mathrm{Cd}$ with lithogenic elements in LE also suggest that their enrichments mainly respond to atmospheric fall out. The increase of $\mathrm{Hg}$ and $\mathrm{Pb}$ enrichments agrees well with higher organic matter deposition and carbonate precipitation that occurred in this lake during the Industrial Period (Morellón et al., 2011; Tables S3 and S4, Fig. 4) suggesting the fixation of these elements to organicbound compounds and carbonates in the sediment. Nevertheless, $\mathrm{Hg}$ and $\mathrm{Pb}$ show a similar trend in both, LE and LM (Figs. 5 and 6) suggesting that the role of increased organic matter and carbonate deposition and preservation has solely enhanced the atmospheric signal preserved in LE sedimentary record. The anomalous increase of Mo in LE is not reflected either in LM or in LB. To our knowledge, there is not any significant Mo source near the lake. A strong correlation of Mo with TOC (0.914) points to the fixation of this element under strong acidic (euxinic) hypolimnetic waters coherent with higher organic deposition in the lake during the last centuries. Indeed, efficient Mo burial in the sediment under strong reducing conditions has been previously reported in different euxinic lacustrine and marine environments (Scott and Lyons, 2012; Wirth et al., 2013).

LB does not show significant trace metals EFs (Table S3, Fig. 4). Although sediment focusing could explain this trend partially, other factors controlling the depositional dynamics in LB may have contributed largely to the lower trace metals EFs: i) the correlation of most of the anthropogenic pollutants with lithogenic elements (Table S2) suggests that they may have reached the lacustrine basin during flood-related run-off events that mobilized trace metals from the soil's watershed. The higher sedimentation rate in LB also highlights an increase in the allocthonous sediment supply to the lake in the studied period. Therefore, a "dilution effect" of trace metals concentrations is expected as observed in other lakes and peatbog systems (Boyle and Birks, 1999; Cornwell, 1986; Pérez-Rodríguez et al., 2015); ii) although the lake waters have likely been well oxygenated during the studied period due to the shallowness of the lake, the sediments themselves may have been through redox changes that may explain the concentration and EFs variability of some trace metals, such as $\mathrm{Cr}$ and $\mathrm{Cu}$, since these elements can be easily mobilized and re-precipitated in the sediment under anoxic/ oxic changes in the lake (Nriagu et al., 1993); iii) sediment (and trace metals) remobilization during erosive underflow events related to hyperpycnal currents entering the lake during run-off events may have also hindered the atmospheric pollution record; iv) significant correlations between TIC and trace metal enrichments $(\mathrm{Hb}, \mathrm{Pb}, \mathrm{As}, \mathrm{Cu}$ and Zn EFs) (Table S3) suggest that these trace metals enrichments might be controlled by trace metal adsorption in carbonates precipitating in the lake (Pérez-Sanz et al., 2014) masking the anthropogenic signal.

\subsubsection{Sediment focusing effect}

Sediment focusing describes the process involving sediment remobilization in shallow lacustrine areas by water currents, gravitational processes and waves and subsequent particles settling in the deeper areas (Lehman, 1975). This process may ultimately control the geochemical composition and heterogeneities in the lacustrine sedimentary sequences (Mackay et al., 2012). Lake morphometry influences sediment focusing with exposed lakes such as LB, resulting in sediment distribution more erratic (Blais and Jacob, 1995). LB shallowness as well as the elevated water surface vs depth ratio and gentle slopes would result in higher remobilization of trace metals within the sediment and larger heterogeneities. On the contrary, the morphometric characteristics of LM and LE, with steep slopes and deeper accumulation areas unaffected by waves favoured sediment (and trace metals) settling and preservation in the deepest areas of the lacustrine basins where the sediment cores were retrieved.

Regarding sediment focusing at a catchment scale, the reduced lake surface/catchment area ratio in LE and LM have diminished the sediment focusing effect favouring the direct atmospheric deposition (and preservation) of trace metals pollutants in the sedimentary record as seen in other eastern Pyrenean lakes - Lake Montcortès, Corella et al., 2017; Lake Redó, (Camarero et al., 1998) - with similar morphometric characteristics. Indeed, trace metals EFs in LB and LE display reasonably similar values with Lake Montcortès EFs in terms of timing and magnitude (Fig. 6). In addition, the transfer of trace elements to the LM sediment should be potentially very effective because the retention of pollutants in the catchment is comparatively low with respect to the catchments in the lowland sites since in LM the watershed is composed 
of bare rock and vegetation is very scarce. Contrarily to LB and LE, the large LB catchment area may have also introduced a time-lag in the transport and deposition of trace metal from the watershed to the lake as sediments may get stored in the watershed by natural barriers and forested areas and pollutants are fixed to soil particles. Indeed, soils under conifer forest (most of LB's watershed area is forested by Pinus uncinata) enhance retention of deposited trace elements because of greater amounts of organic acids (Lovett and Kinsman, 1990). The delayed increase of anthropogenic trace metal during the onsets of Industrialization and the Great Acceleration in LB suggests a time-lag response of $\sim 40-90$ yrs., likely reflecting sediment focussing in the catchment. Furthermore, the comparison between mean trace metal EFs in LB with other nearby lakes (i.e. Lake Marboré, Lake Estanya, Lake Montcortès) suggests that depositional processes in LB (most likely sediment focussing) result in a 45-60\% reduction in the lake's sensitiveness to record trace mental atmospheric pollution.

\subsubsection{Altitudinal effect on trace metal deposition}

Differences in altitude across the Southern Central Pyrenees generate a strong climate gradient in terms of temperature and precipitation variability that may influence trace metal deposition onto the lake surfaces. Increasing precipitation with altitude should enhance trace metal deposition at higher elevation sites (2000 mm mean annual precipitation in LM and LB Vs $470 \mathrm{~mm}$ in LE). Indeed, direct measurements of trace metals ( $\mathrm{Zn}, \mathrm{Ni}, \mathrm{Cu}, \mathrm{As}, \mathrm{Cd}$ and $\mathrm{Pb}$ ) atmospheric fluxes in the Southern Pyrenees accounts for only 5-20\% of dry deposition implying that wet air masses controls the deposition of these trace metals (Bacardit and Camarero, 2010b). Our results agree well with the above mentioned monitoring study since mean concentrations of $\mathrm{Cd}, \mathrm{Pb}, \mathrm{As}, \mathrm{Cu}$, Ni and $\mathrm{Zn}$ are significantly lower in LE compared to LB and LM, where there is a 4fold increase in mean annual precipitation inducing trace metals wet deposition. Nevertheless, although metal concentrations are lower in LE, metal enrichment factors over altitude indicated opposite patterns of distribution. Thus, a 1.4 general increase in $\mathrm{Hg}, \mathrm{Cd}, \mathrm{Cr}, \mathrm{Pb}, \mathrm{Ni}$ and Zn EFs is observed in the lower-elevation LE with respect to the highaltitude LM (Table S4). This inverse relationship with altitude indicates that local pollution inputs are significant in the lowlands. Conversely, site-specific features such as higher organic matter deposition and stronger reducing bottom conditions in LE could have played an enhancing role. However, the same pattern has been observed in a previous study in Pyrenean soils across an altitudinal gradient where higher enrichments of $\mathrm{Ni}, \mathrm{Cu}, \mathrm{Zn}$ and $\mathrm{Pb}$ were found at lower elevation sites due to the influence of local pollution sources - as roads, industries, human activities - not observed in soils and winter snow cover at higher altitude (Bacardit and Camarero, 2010a, 2010b). Low-altitude trajectories of air masses, close to the emission areas and crossing the mixed boundary layer in the lower atmosphere, may result in the higher enrichment of trace elements in the low-elevation areas (Bacardit and Camarero, 2009) as recorded in LE. Seasonality may also explain the higher trace metals enrichment at low-elevation LE since thermal inversion during the cold season produced a capping effect, thereby limiting the transport of atmospheric pollutants to higher altitude areas (Bacardit and Camarero, 2009).

The high altitude LM can be considered as representative of background, global atmospheric pollution since long-range transport of atmospheric pollutants mostly takes place above the mixing boundary layer. Although winter snow and ice cover may have also reduced trace metals deposition in high altitude LM, trace metals deposition in the Southern Pyrenees mainly occurs in summer when more frequent inland air masses (enriched in trace elements) and a thicker atmospheric mixed layer occurs (Bacardit and Camarero, 2009).

Enhanced $\mathrm{Hg}$ deposition is favoured by colder temperatures and higher precipitation at high-elevation areas where atmospheric $\mathrm{Hg}$ can be oxidized to divalent $\mathrm{Hg}\left(\mathrm{Hg}^{\mathrm{II}}\right)$, and accumulated onto lake's surfaces. Therefore, the climatic effect most likely controlled the increased in $\mathrm{Hg}$ concentration in soils with altitude along a transect across the
Central Pyrenees previously reported by McGee and Vallejo (1996). Surprisingly we see the opposite pattern in the studied lakes with the highest Hg concentrations occurring at the low-elevation LE (Figs. 3, 4 and 5) where warmer and less humid conditions occur. We argue that the $\mathrm{Hg}$ fixation to organic matter compounds in organic-rich sediments such as LE directly compete with the climate effect controlling Hg deposition in high elevated areas.

\subsection{Trace metals atmospheric pollution in Southern Pyrenees since the on- set of industrialization}

The analysis of sediment cores in LE, LB and LM provided a record of anthropogenic trace metals historical contamination in the Southern Pyrenees since the $15^{\text {th }}$ century. The significant EFs increases of anthropogenic pollutants $\mathrm{Hg}, \mathrm{Cd}, \mathrm{Pb}$, and $\mathrm{Zn}$ in LE and LM clearly shows the acceleration of atmospheric pollution in NE Spain with the advent of the Industrial Revolution ( $1760 \mathrm{CE}$ ) consistent with the increasing demand of ore resources in Europe. On the other hand, trace metals enrichment in LB shows a delayed pollution signal due to the intrinsic morphological characteristics of the lake and its watershed. The trace metal burden on soils from LB watersheds implies that pollutants can be remobilized although trace metals atmospheric deposition is currently declining in the Pyrenean soils (Camarero, 2017).

\subsubsection{Mercury}

Mercury EFs remain constant with average values $~ 1$ during the PreIndustrial Period except for a short period at the early $17^{\text {th }}$ century where Hg EF showed a 2-fold increase in LE. This increase in Hg deposition might be related to an increase in mercury production (and related emissions) in Almadén (Southern Spain) during the first half of the century (Fig. 5) where 8740 tons of mercury where extracted from these mines and shipped to America for use in silver mining in the Spanish colonies after the discovery of the patio amalgamation (Hylander and Meili, 2003). A recent study in a similar karstic lake - in terms of limnology, catchment size and bedrock - located in the eastern Pyrenees (i.e. Lake Montcortès) also suggested mining activities in Almadén (Fig. 1A) as a possible source of $\mathrm{Hg}$ pollution in the Pyrenees (Corella et al., 2017). Hg EFs in LE became again close to 1 during the second half of the $17^{\text {th }}$ century likely related to the exhaustion of $\mathrm{Hg}$ resources in Almadén during this period. The 3.7 and 2.6 fold increase in mercury recorded in LE and LM respectively during the Industrial Period is in agreement with other studies in continental sites from northern Spain (Corella et al., 2017; Martínez Cortizas et al., 2012).

Both LE and LM show a similar Hg enrichment trends during the Industrial Period that suggest regional (rather than local) Hg sources. A progressive increase in $\mathrm{Hg}$ EFs in LE and LM took place at $1770 \mathrm{CE}$ mirroring the mercury production in Almadén that boosted since the onset of the Industrial Period (Hylander and Meili, 2003). Maximum EFs were recorded at the turn of the $20^{\text {th }}$ century with EFs of 5.7 and 3.7 for LE and LM respectively in $\sim 1890$ CE related to an abrupt increase of $\mathrm{Hg}$ primary anthropogenic emissions to the atmosphere (Horowitz et al., 2014; Hudson et al., 1995; Pirrone et al., 1998; Streets et al., 2017). These emissions were mostly related to mercury use for amalgamation in large-scale mining (Hylander and Meili, 2003; Pirrone et al., 1998), especially in the northern Hemisphere, where recent estimates document the highest emissions of all time with up to $3 \mathrm{Gg} / \mathrm{yr}$ of Hg emissions released to air (Streets et al., 2017) (Fig. 5). The higher $\mathrm{Hg}$ EF found in LE could also be explained by the use of $1^{\text {st }}$ generation (pre 1940 CE) Hg-bearing fertilizers associated to agricultural practices in the lowlands during this period.

A sharp decline in Hg enrichment in LM and LE occurred associated to the lower $\mathrm{Hg}$ emissions during the periods between the two World Wars when $\mathrm{Hg}$ levels fell to roughly half the previous values (Horowitz et al., 2014; Streets et al., 2017). Maximum peaks in the three lakes occurred between 1950 and 1990 - the Great Acceleration - as a consequence of increased $\mathrm{Hg}$ production in Almadén and the 
raise in $\mathrm{Hg}$ global production and anthropogenic emissions to the atmosphere related to widespread industrial uses of mercury (e.g. paint, batteries, chlor-alkali plants) (Horowitz et al., 2014; Hylander and Meili, 2003) (Fig. 5). The implementation of environmental regulations on $\mathrm{Hg}$ uses and related emissions in North America and Europe during the late $20^{\text {th }}$ century (Zhang et al., 2016) was efficiently recorded in the Southern Pyrenees where the studied lakes show an abrupt decline in $\mathrm{Hg}$ EFs since the 1990s. Nevertheless, Hg enrichment during the early $21^{\text {st }}$ century still doubled Pre-industrial levels.

\subsubsection{Lead, zinc, cadmium and copper}

Enrichment of $\mathrm{Pb}, \mathrm{Zn}$ and $\mathrm{Cd}$ were modest in Southern Central Pyrenees during the Pre-industrial Period (Fig. 6), although regional records show relatively high values during Roman times (Camarero et al., 1998; Mata et al., 2013; Oliva-Urcia et al., 2018). These trace metals EFs slightly increased since during the late $18^{\text {th }}$ century and showed a progressive increase since the 1840 s reaching the maximum peaks at the turn of the $20^{\text {th }}$ century with a three-fold enrichment in Pb in LE and $\mathrm{LM}$. The increase in $\mathrm{Pb}$ atmospheric fall-out may respond to the increasing trend in lead pollution in Europe, mainly related to higher Pb production, smelting techniques and coal combustion in western Europe during this period (Martínez Cortizas et al., 2012; Rosman et al., 2000; Schwikowski et al., 2004; Shotyk et al., 1998; von Gunten et al., 1997) (Fig. 6). Indeed, the exponential increase in coal combustion in Europe since $1850 \mathrm{CE}$ (Fig. 6) has been proposed as the main source leading to enhanced $\mathrm{Pb}$ deposition in coastal sediments and peatbogs from northern Spain (Kanala salt marsh (Leorri et al., 2014); Chapo de Lamoso peatbog (Martínez Cortizas et al., 2012)). The ${ }^{208} \mathrm{~Pb} /{ }^{206} \mathrm{~Pb}$, ${ }^{208} \mathrm{~Pb} /{ }^{204} \mathrm{~Pb},{ }^{207} \mathrm{~Pb} /{ }^{204} \mathrm{~Pb}$ and ${ }^{207} \mathrm{~Pb} /{ }^{206} \mathrm{~Pb}$ isotopic ratios in LM agree well with these records before the onset of Industrialization. However, these ratios do not follow the same trend during the second half of the $19^{\text {th }}$ century (Fig. 6 ) suggesting a different source driving the increase in atmospheric $\mathrm{Pb}$ deposition in the Southern Central Pyrenees. The agreement between the $\mathrm{Pb}$ isotopic ratios of LM sediments and galena samples from local galena mines (Parzán and Cierco) between 1860 CE and 1930 CE (Figs. 1 and 7 and Fig. S1) suggests that intensive large-scale $\mathrm{Pb}$ mining activities in the Southern Central Pyrenees (Camarero et al., 1998; Corella et al., 2017; Nieto-Callen, 1996) also controlled $\mathrm{Pb}$ deposition in the area during this period.

Enrichment of cadmium and zinc are also in agreement with $\mathrm{Pb}$ mining in the region since these two elements mainly constitute byproducts of lead mining and smelting techniques (Dudka and Adriano, 1997). In these mines, galena was extracted in F-Pb-Zn vein deposits (Fanlo et al., 1998; Subías et al., 2015) and subsequently smelted in local and regional kilns emitting large amounts of these elements to the local atmosphere. $\mathrm{Cd}$ and $\mathrm{Zn}$ mean enrichment of 1.3 is seen in LM during Industrialization in agreement with the regional enrichment of these two elements (Bacardit and Camarero, 2009) while Cd and $\mathrm{Zn}$ show a two-fold increase in LE partially due to magnifying effect of higher organic deposition and changes in the lake's redox conditions in the metals enrichments. Therefore, historical $\mathrm{Pb}$ production and metallurgy in the area would have emitted significant amounts of these trace metals to the local atmosphere as reflected in the EFs of these two metals during this period. Global $\mathrm{Pb}, \mathrm{Cd}$ and $\mathrm{Zn}$ emission inventories (e.g. Nriagu (1979) and references therein) showed reduced emissions of these trace metals compared to the emission rates during the Great Acceleration also pointing at local mining sources of these trace metals to explain their highest values in Southern Pyrenees during this period.

A sharp decline with a return to almost pre-industrial EFs of $\mathrm{Zn}, \mathrm{Cd}$ and $\mathrm{Pb}$ in both $\mathrm{LE}$ and $\mathrm{LM}$ and a return towards more radiogenic $\mathrm{Pb}$ isotopic values in LM occurred in the 1930s in both LE and LM likely related to the reduced emissions associated to the economic recession at that time and the closure of Parzán mines.

The environmental response of the use of leaded gasoline, which greatly increased since 1950 and contributed to $>60 \%$ of total emitted
$\mathrm{Pb}$ (Schwikowski et al., 2004) is well seen in the three lakes. Nevertheless, $\mathrm{Pb}$ enrichment factors in LE almost doubled LM most likely due to the traffic-induced lead emissions from the highway located $20 \mathrm{~km}$ south of LE. Indeed, road transport has consistently remained the largest emission source for the period 1955-1995 (von Storch et al., 2003). The highest Pb enrichment in the late 1980s in the three lakes and the lowest radioactive isotopes found in LM (Fig. 6) agrees well with the highest lead emissions in Spain with $>3000$ tons emitted per year (Eurostat, 1998; Pacyna et al., 2007) (Fig. 6). The drastic reduction of Pb deposition in 2003 to current levels is also most likely related to the total ban of leaded gasoline in Spain in 2001.

Zinc enrichment associated to atmospheric fall out observed in LE might also be related to the intensification of the road transport since this metal was an important additive in the manufacture of the rubber used in tires during this period (Stigliani et al., 1993). Nevertheless, Zn correlates well with siliciclastic material derived from erosion of the watershed (Table S2). Intensive farming activities in LE's watershed controlled catchment erosion and soil loss since the mid-20th century (López-Vicente et al., 2008) intensifying the delivery of terrigenous and terrestrial organic compounds to the lacustrine basin (Morellón et al., 2011). Second generation (post 1940 CE) Zn-bearing fertilizers associated to these agricultural practices may have constituted an additional source of this trace metal to the lake as seen in other similar karstic lake systems from southern Spain (Valero-Garcés et al., 2006). Besides these local sources, EFs increase of $\mathrm{Pb}$ and $\mathrm{Zn}$ during the Great Acceleration is also in agreement with the boost of their emissions at a global scale associated with the increase of industrial activities worldwide (Nriagu, 1979, 1996).

Copper shows the largest enrichment heterogeneity in all the studied lakes displaying the highest EFs in LB since the Pre-Industrial Period. The presence of Cu-rich ore deposits close to this lake (Eureka mine, Fig. 1) suggest historical local mining activities extracting copper resources in the area during the last centuries that were intensified between 1850 and $1950 \mathrm{CE}$. Cu EFs does not follow the increasing trend of Cu global emission inventories between 1950s and 1990s (Nriagu, 1996) suggesting that intrinsic lacustrine factors (ie. redox variability) may hinder the atmospheric signal. The slight $\mathrm{Cu}$ and $\mathrm{Zn}$ EFs decrease seen during the last decades across the Southern Pyrenees (Fig. 6) agrees well with the reduction in $\mathrm{Cu}$ and $\mathrm{Zn}$ atmospheric stock attributed to advances in pollution control technology in production (Rauch and Pacyna, 2009).

\section{Conclusions}

Trace metal concentrations and enrichment factors in sediments from three lakes located across an altitudinal gradient in Southern Central Pyrenees (Marboré, Basa de la Mora and Estanya) unravel the history of metals pollution for the last six centuries in this region. Intrinsic spatial (location), depositional (sediment focusing) and morphometric (size of the watershed, vegetation cover, lake's surface Vs depth ratio) characteristics of the lakes influence the lake's ability to record trace metals atmospheric fall-out episodes in the region. Positive enrichments of mercury and lead and, in a lesser extent, $\mathrm{Cd}, \mathrm{Cu}$ and $\mathrm{Zn}$, in LE and LM have highlighted the environmental impact on alpine lakes since the advent of industrialization. Local mining and regional smelting activities in NE Spain are the most likely source of these anthropogenic trace metals between 1840 and 1930. The highest mercury deposition occurred at 1890 and $~ 1960$. Mercury anthropogenic enrichment factor increases correlate well with the raise in $\mathrm{Hg}$ production in Almadén (S Spain) and it is synchronous to high mercury emissions inferred by models.

High-altitude, pristine LM records most efficiently past regional long-range atmospheric deposition of trace metals while the enrichment of anthropogenic trace metals in low-elevation LE also respond to variable biogeochemical processes in the lake (i.e. redox variability and organic matter deposition) controlled by specific limnological 
features (water depth, morphometry) and local factors (regional climate variability, local pollution sources due to its proximity to populated areas and infrastructures). Sediment focusing in LB greatly reduced the lake sensitiveness to record historical pollution of trace metals.

The general increasing trend of $\mathrm{Hg}$, $\mathrm{Pb}$ and $\mathrm{Zn}$ EFs recorded in Southern Central Pyrenees correlates fairly well with nearby natural archives and regional and global emission inventories suggesting a mixed signal between local and global sources of trace metal pollution.

This study demonstrates the importance of combining multi-trace elements using different lacustrine settings to discriminate local Vs regional-scale human-induced environmental changes. We introduce a note of caution for paleolimnological reconstructions of historical pollution using single archives, since site-specific processes may bias the pollution signal. The multi-archive strategy carried out in this study resulted in a suitable approach to reconstruct long-term regional air pollution evolution. This paleolimnological approach may also provide a wealth of environmental information to stake holders to understand the environmental response to anthropogenic pressure on aquatic ecosystems as wells as to evaluate the long-term effectiveness of recent environmental regulations (i.e. trace metal emission controls). In this line, trace metal enrichments in the studied sites have decreased considerably since 1990s as a consequence of decreased emissions in Europe and North America. Nevertheless, the persistence of trace metal pollution overtime led to an environmental legacy affecting the sediment quality of the lake systems. Thus, the trace metals stored in these natural sinks (lake sediments and soils) could be remobilized in a near future threatening fragile mountain ecosystems. Therefore, understanding this environmental legacy (i.e. trace metal depositional history in natural archives from past anthropogenic emissions) should help environmental policy makers to design future "clean air, soil and water" policies.

\section{Acknowledgments}

This work was supported by the Spanish Ministry of Economy and Competitiveness (MINECO) projects MEDLANT (CGL2016-76215-R) and HYVARMED (CGL2013-42645-P), the National Park Autonomous Organization (HORDA project, ref. 083/2009) and the Sobrarbe Geopark through the project "Reconstrucción de la minería histórica en la Comarca del Sobrarbe y su impacto ambiental durante el Antropoceno". J.P.C. was supported by a MINECO postdoctoral grant (ref FPDI-201317443) and currently holds a Juan de la Cierva - Incorporación postdoctoral contract also funded by MINECO (ref IJCI-2015-23839). We also acknowledge the "Comarca del Sobrarbe" for his enthusiastic support. The authors thank for technical and human support provided by SGIker of UPV/EHU and European funding (ERD and ESF).

\section{Appendix A. Supplementary data}

Supplementary data to this article can be found online at https://doi. org/10.1016/j.scitotenv.2018.07.160.

\section{References}

Amos, H.M., Jacob, D.J., Streets, D.G., Sunderland, E.M., 2013. Legacy impacts of all-time anthropogenic emissions on the global mercury cycle. Glob. Biogeochem. Cycles 27, 410-421.

Amos, H.M., Sonke, J.E., Obrist, D., Robins, N., Hagan, N., Horowitz, H.M., Mason, R.P., Witt, M., Hedgecock, I.M., Corbitt, E.S., 2015. Observational and modeling constraints on global anthropogenic enrichment of mercury. Environ. Sci. Technol. 49, 4036-4047.

Bacardit, M., Camarero, L., 2009. Fluxes of Al, Fe, Ti, Mn, Pb, Cd, Zn, Ni, Cu, and As in monthly bulk deposition over the Pyrenees (SW Europe): the influence of meteorology on the atmospheric component of trace element cycles and its implications for high mountain lakes. J. Geophys. Res. Biogeosci. 114, G00D02. https://doi.org/ 10.1029/2008JG000732.

Bacardit, M., Camarero, L., 2010a. Atmospherically deposited major and trace elements in the winter snowpack along a gradient of altitude in the Central Pyrenees: the seasonal record of long-range fluxes over SW Europe. Atmos. Environ. 44, 582-595.
Bacardit, M., Camarero, L., 2010b. Major and trace elements in soils in the Central Pyrenees: high altitude soils as a cumulative record of background atmospheric contamination over SW Europe. Environ. Sci. Pollut. Res. 17, 1606-1621.

Bacardit, M., Krachler, M., Camarero, L., 2012. Whole-catchment inventories of trace metals in soils and sediments in mountain lake catchments in the Central Pyrenees: apportioning the anthropogenic and natural contributions. Geochim. Cosmochim. Acta 82, 52-67.

Biester, H., Bindler, R., Martinez-Cortizas, A., Engstrom, D.R., 2007. Modeling the past atmospheric deposition of mercury using natural archives. Environ. Sci. Technol. 41, $4851-4860$

Blais, J.M., Jacob, K., 1995. The influence of lake morphometry on sediment focusing. Limnol. Oceanogr. 40, 582-588.

Boës, X., Rydberg, J., Martinez-Cortizas, A., Bindler, R., Renberg, I., 2011. Evaluation of conservative lithogenic elements ( $\mathrm{Ti}, \mathrm{Zr}, \mathrm{Al}$, and $\mathrm{Rb}$ ) to study anthropogenic element enrichments in lake sediments. J. Paleolimnol. 46, 75-87.

Boyle, J.F., Birks, H.J.B., 1999. Predicting heavy metal concentrations in the surface sediments of Norwegian Headwater Lakes from atmospheric deposition: an application of a simple sediment-water partitioning model. Water Air Soil Pollut. 114, 27-51.

Camarero, L., 2003. Spreading of trace metals and metalloids pollution in lake sediments over the Pyrenees. J. Phys. IV 249-253 EDP sciences.

Camarero, L., 2017. Atmospheric chemical loadings in the high mountain: current forcing and legacy pollution. In: Catalan, J., Ninot, J.M., Aniz, M.M. (Eds.), High Mountain Conservation in a Changing World. Springer International Publishing, Cham, pp. 325-341.

Camarero, L., Masqué, P., Devos, W., Ani-Ragolta, I., Catalan, J., Moor, H.C., Pla, S., SanchezCabeza, J.A., 1998. Historical variations in lead fluxes in the Pyrenees (Northeast Spain) from a dated Lake sediment Core. Water Air Soil Pollut. 105, 439-449.

Camarero, L., Botev, I., Muri, G., Psenner, R., Rose, N., Stuchlik, E., 2009. Trace elements in alpine and arctic lake sediments as a record of diffuse atmospheric contamination across Europe. Freshw. Biol. 54, 2518-2532.

Catalan, J., 2015. Tracking long-range atmospheric transport of trace metals, polycyclic aromatic hydrocarbons, and organohalogen compounds using lake sediments of mountain regions. In: Blais, J.M., Rosen, M.R., Smol, J.P. (Eds.), Environmental Contaminants: Using Natural Archives to Track Sources and Long-Term Trends of Pollution. Springer Netherlands, Dordrecht, pp. 263-322.

Chernyshev, I., Chugaev, A., Shatagin, K., 2007. High-precision Pb isotope analysis by multicollector-ICP-mass-spectrometry using $205 \mathrm{Tl} / 203 \mathrm{Tl}$ normalization: optimization and calibration of the method for the studies of $\mathrm{Pb}$ isotope variations. Geochem. Int. 45, 1065-1076

Corella, J., Valero-Garcés, B., Wang, F., Martínez-Cortizas, A., Cuevas, C., Saiz-Lopez, A., 2017. 700 years reconstruction of mercury and lead atmospheric deposition in the Pyrenees (NE Spain). Atmos. Environ. 155, 97-107.

Cornwell, J.C., 1986. Diagenetic trace-metal profiles in Arctic lake sediments. Environ. Sci. Technol. 20, 299-302.

Dudka, S., Adriano, D.C., 1997. Environmental impacts of metal ore mining and processing: a review. J. Environ. Qual. 26, 590-602.

Eurostat, 1998. Data Sets about Gasoline Sales and Lead Content in Gasoline in 12 EUNations, Statistical Office of the European. Communities, Brussels.

Fanlo, I., Touray, J.C., Subías, I., Fernández-Nieto, C., 1998. Geochemical patterns of a sheared fluorite vein, Parzan, Spanish Central Pyrenees. Mineral. Deposita 33, 620-632.

García-Alix, A., Jimenez-Espejo, F., Lozano, J., Jiménez-Moreno, G., Martinez-Ruiz, F., Sanjuán, L.G., Jiménez, G.A., Alfonso, E.G., Ruiz-Puertas, G., Anderson, R.S., 2013. Anthropogenic impact and lead pollution throughout the Holocene in Southern Iberia. Sci. Total Environ. 449, 451-460.

Gascón-Díez, E., Corella, J.P., Adatte, T., Thevenon, F., Loizeau, J.L., 2017. High-resolution reconstruction of the 20th century history of trace metals, major elements, and organic matter in sediments in a contaminated area of Lake Geneva, Switzerland. Appl. Geochem. 78, 1-11.

González-Sampériz, P., Aranbarri, J., Pérez-Sanz, A., Gil-Romera, G., Moreno, A., Leunda, M., Sevilla-Callejo, M., Corella, J.P., Morellón, M., Oliva, B., 2017. Environmental and climate change in the Southern Central Pyrenees since the Last Glacial maximum: a view from the lake records. Catena 149, 668-688.

Han, F.X., Banin, A., Su, Y., Monts, D.L., Plodinec, J.M., Kingery, W.L., Triplett, G.E., 2002. Industrial age anthropogenic inputs of heavy metals into the pedosphere. Naturwissenschaften 89, 497-504.

Hillman, A.L., Abbott, M.B., Yu, J., Bain, D.J., Chiou-Peng, T., 2015. Environmental legacy of copper metallurgy and Mongol silver smelting recorded in Yunnan Lake sediments. Environ. Sci. Technol. 49, 3349-3357.

Hillman, A.L., Abbott, M.B., Valero-Garcés, B., Morellon, M., Barreiro-Lostres, F., Bain, D.J., 2017. Lead pollution resulting from Roman gold extraction in northwestern Spain. The Holocene 27 (10), 1465-1474.

Horowitz, H.M., Jacob, D.J., Amos, H.M., Streets, D.G., Sunderland, E.M., 2014. Historical mercury releases from commercial products: global environmental implications. Environ. Sci. Technol. 48, 10242-10250.

Hudson, R.J.M., Gherini, S.A., Fitzgerald, W.F., Porcella, D.B., 1995. Anthropogenic influences on the global mercury cycle: a model-based analysis. Water Air Soil Pollut. $80,265-272$

HYDE, 2017. History database of the global environment. Metal Production Data. PBL Netherlands Environmental Assessment Agency.

Hylander, L.D., Meili, M., 2003. 500 years of mercury production: global annual inventory by region until 2000 and associated emissions. Sci. Total Environ. 304, 13-27.

Lehman, J.T., 1975. Reconstructing the rate of accumulation of lake sediment: the effect of sediment focusing. Quat. Res. 5, 541-550.

Leorri, E., Mitra, S., Irabien, M.J., Zimmerman, A.R., Blake, W.H., Cearreta, A., 2014. A 700year record of combustion-derived pollution in northern Spain: tools to identify the Holocene/Anthropocene transition in coastal environments. Sci. Total Environ. 470, 240-247. 
Leunda, M., González-Sampériz, P., Gil-Romera, G., Aranbarri, J., Moreno, A., Oliva-Urcia, B., Sevilla-Callejo, M., Valero-Garcés, B., 2017. The Late-Glacial and Holocene Marboré Lake sequence (2612m a.s.l., Central Pyrenees, Spain): testing high altitude sites sensitivity to millennial scale vegetation and climate variability. Glob. Planet. Chang. 157, 214-231.

López-Vicente, M., Navas, A., Machín, J., 2008. Modelling soil detachment rates in rainfed agrosystems in the south-central Pyrenees. Agric. Water Manag. 95, 1079-1089.

Lovett, G.M., Kinsman, J.D., 1990. Atmospheric pollutant deposition to high-elevation ecosystems. Atmos. Environ. Part A 24, 2767-2786.

MacDonald, D.D., Ingersoll, C.G., Berger, T.A., 2000. Development and evaluation of consensus-based sediment quality guidelines for freshwater ecosystems. Arch. Environ. Contam. Toxicol. 39, 20-31.

Mackay, E.B., Jones, I.D., Folkard, A.M., Barker, P., 2012. Contribution of sediment focussing to heterogeneity of organic carbon and phosphorus burial in small lakes. Freshw. Biol. 57, 290-304.

Martínez Cortizas, A., Peiteado Varela, E., Bindler, R., Biester, H., Cheburkin, A., 2012. Reconstructing historical $\mathrm{Pb}$ and $\mathrm{Hg}$ pollution in NW Spain using multiple cores from the Chao de Lamoso bog (Xistral Mountains). Geochim. Cosmochim. Acta 82, 68-78.

Martínez-Cortizas, A., Pontevedra-Pombal, X., Muñoz, J.C.N., García-Rodeja, E., 1997. Four thousand years of atmospheric $\mathrm{Pb}, \mathrm{Cd}$ and $\mathrm{Zn}$ deposition recorded by the Ombrotrophic peat bog of Penido Vello (northwestern Spain). Water Air Soil Pollut. 100, 387-403.

Martinez-Cortizas, A., Pontevedra-Pombal, X., García-Rodeja, E., Nóvoa, M.J.C., Shotyk, W., 1999. Mercury in a Spanish peat bog: archive of climate change and atmospheric metal deposition. Science 284, 939-942.

Martín-Puertas, C., Jiménez-Espejo, F., Martínez-Ruiz, F., Nieto-Moreno, V., Rodrigo, M., Mata, M.P., Valero-Garcés, B.L., 2010. Late Holocene climate variability in the southwestern Mediterranean region: an integrated marine and terrestrial geochemical approach. Clim. Past 6, 807-816.

Mata, M.P., Moreno, A., Oliva-Urcia, B., Valero-Garcés, B.L., Rico, T., 2013. Registro histórico de la contaminación atmosférica por Pb en el Lago de Marboré (P.N. de Ordesa y Monte Perdido). Macla. 17 pp. 71-72.

McGee, E.J., Vallejo, V.R., 1996. Long-range transport and soil interception of atmophile elements on a transect across the Pyrenees. Proceedings of Eurotrac Symposium. 96, pp. 307-314.

Morellón, M., Valero-Garcés, B., Vegas-Vilarrúbia, T., González-Sampériz, P., Romero, Ó., Delgado-Huertas, A., Mata, P., Moreno, A., Rico, M., Corella, J.P., 2009a. Lateglacial and Holocene palaeohydrology in the western Mediterranean region: the Lake Estanya record (NE Spain). Quat. Sci. Rev. 28, 2582-2599.

Morellón, M., Valero-Garcés, B.L., Anselmetti, F., Ariztegui, D., Schnellmann, M., Moreno, A., Mata, P., Rico, M., Corella, J.P., 2009b. Late Quaternary deposition and facies model for karstic Lake Estanya (NE Spain). Sedimentology 56, 1505-1534.

Morellón, M., Valero-Garcés, B., González-Sampériz, P., Vegas-Vilarrúbia, T., Rubio, E., Rieradevall, M., Delgado-Huertas, A., Mata, P., Romero, Ó., Engstrom, D., LópezVicente, M., Navas, A., Soto, J., 2011. Climate changes and human activities recorded in the sediments of Lake Estanya (NE Spain) during the Medieval Warm Period and Little Ice Age. J. Paleolimnol. 46, 423-452.

Nicolás-Martínez, P.M., 2013. Morfología del circo de Tucarroya (Macizo de Monte Perdido, Pirineo aragonés). Cuadernos de Investigación Geográfica 7, 51-80.

Nieto-Callen, J.J., 1996. El proceso sidero-metalúrgico altoaragones: Los valles de Bielsa y Gistain en la Edad Moderna (1565-1800). Llull. 19 pp. 471-507.

Nriagu, J.O., 1979. Global inventory of natural and anthropogenic emissions of trace metals to the atmosphere. Nature 279, 409-411.

Nriagu, J.O., 1989. Natural Versus Anthropogenic Emissions of Trace Metals to the Atmosphere. In: Pacyna, J.M., Ottar, B. (Eds.), Control and Fate of Atmospheric Trace Metals. Springer Netherlands, Dordrecht, pp. 3-13.

Nriagu, J.O., 1996. A history of global metal pollution. Science 272, 223.

Nriagu, J.O., Beaubien, S., Blowes, D., 1993. Blowes chemistry of chromium in lakes. Environ. Rev. 1, 104-120.

Olendrzyński, K., Anderberg, S., Stigliani, W., Bartnicki, J., Pacyna, J., 1996. Atmospheric emissions and depositions of cadmium, lead, and zinc in Europe during the period 1955-1987. Environ. Rev. 4, 300-320.

Oliva-Urcia, B., Moreno, A., Leunda, M., Valero-Garcés, B., González-Sampériz, P., GilRomera, G., Mata, M.P., 2018. Last deglaciation and Holocene environmental change at high altitude in the Pyrenees: the geochemical and paleomagnetic record from Marboré Lake (N Spain). J. Paleolimnol. 59, 349-371.

Pacyna, J.M., Pacyna, E.G., 2001. An assessment of global and regional emissions of trace metals to the atmosphere from anthropogenic sources worldwide. Environ. Rev. 9, 269-298.

Pacyna, E.G., Pacyna, J.M., Fudala, J., Strzelecka-Jastrzab, E., Hlawiczka, S., Panasiuk, D. Nitter, S., Pregger, T., Pfeiffer, H., Friedrich, R., 2007. Current and future emissions of selected heavy metals to the atmosphere from anthropogenic sources in Europe. Atmos. Environ. 41, 8557-8566.

Pacyna, J.M., Pacyna, E.G., Aas, W., 2009. Changes of emissions and atmospheric deposition of mercury, lead, and cadmium. Atmos. Environ. 43, 117-127.

Peinado Lorca, M., Rivas-Martínez, S., 1987. In: Abierta, C.A. (Ed.), La vegetación de España. Servicio de Publicaciones de la Universidad de Alcalá, Alcalá de Henares, p. 544.

Pérez-Rodríguez, M., Horák-Terra, I., Rodríguez-Lado, L., Aboal, J.R., Martínez Cortizas, A. 2015. Long-term ( $\sim 57 \mathrm{ka})$ controls on mercury accumulation in the Souther hemisphere reconstructed using a peat record from Pinheiro mire (Minas Gerais, Brazil). Environ. Sci. Technol. 49, 1356-1364.

Pérez-Sanz, A., González-Sampériz, P., Moreno, A., Valero-Garcés, B., Gil-Romera, G., Rieradevall, M., Tarrats, P., Lasheras-Álvarez, L., Morellón, M., Belmonte, A., Sancho, C., Sevilla-Callejo, M., Navas, A., 2014. Holocene climate variability, vegetation dynamics and fire regime in the Central Pyrenees: the Basa de la Mora sequence (NE Spain). Quat. Sci. Rev. 73, 149-169.

Pirrone, N., Allegrini, I., Keeler, G.J., Nriagu, J.O., Rossmann, R., Robbins, J.A., 1998. Historical atmospheric mercury emissions and depositions in North America compared to mercury accumulations in sedimentary records. Atmos. Environ. 32, 929-940.

Rauch, J.N., Pacyna, J.M., 2009. Earth's global Ag, Al, Cr, Cu, Fe, Ni, Pb, and Zn cycles. Glob. Biogeochem. Cycles 23, GB2001. https://doi.org/10.1029/2008GB003376.

Rosman, K.J.R., Chisholm, W., Hong, S., Candelone, J.-P., Boutron, C.F., 1997. Lead from Carthaginian and Roman Spanish mines isotopically identified in Greenland Ice Dated from 600 B.C. to 300 A.D. Environ. Sci. Technol. 31, 3413-3416.

Rosman, K.J.R., Ly, C., Van de Velde, K., Boutron, C.F., 2000. A two century record of lead isotopes in high altitude Alpine snow and ice. Earth Planet. Sci. Lett. 176, 413-424.

Rubio, B., Nombela, M.A., Vilas, F., 2000. Geochemistry of Major and Trace Elements in Sediments of the Ria de Vigo (NW Spain): an assessment of metal pollution. Mar. Pollut. Bull. 40, 968-980.

Sánchez-España, J., Mata, M.P., Vegas, J., Morellón, M., Rodríguez, J.A., Salazar, A., Yusta, I., 2018. Limnochemistry of the remote, high mountain Lake Marboré (Ordesa and Monte Perdido National Park, Central Pyrenees): Stratification dynamics and trace metal anomalies. Limnetica 37, 85-103.

Schwikowski, M., Barbante, C., Doering, T., Gaeggeler, H.W., Boutron, C., Schotterer, U. Tobler, L., Van de Velde, K., Ferrari, C., Cozzi, G., Rosman, K., Cescon, P., 2004. Post17th-Century changes of European lead emissions recorded in high-altitude alpine snow and ice. Environ. Sci. Technol. 38, 957-964.

Scott, C., Lyons, T.W., 2012. Contrasting molybdenum cycling and isotopic properties in euxinic versus non-euxinic sediments and sedimentary rocks: Refining the paleoproxies. Chem. Geol. 324, 19-27.

Serrano, O., Mateo, M., Dueñas-Bohórquez, A., Renom, P., López-Sáez, J.A., Cortizas, A.M. 2011. The Posidonia oceanica marine sedimentary record: a Holocene archive of heavy metal pollution. Sci. Total Environ. 409, 4831-4840.

Shotyk, W., Weiss, D., Appleby, P.G., Cheburkin, A.K., Frei, R., Gloor, M., Kramers, J.D. Reese, S., Van Der Knaap, W.O., 1998. History of atmospheric lead deposition since 12,370 14C yr BP from a Peat Bog, Jura Mountains, Switzerland. Science 281, $1635-1640$.

Stigliani, W.M., Jaffe, P.R., Anderberg, S., 1993. Heavy metal pollution in the Rhine basin. Environ. Sci. Technol. 27, 786-793.

Streets, D.G., Devane, M.K., Lu, Z., Bond, T.C., Sunderland, E.M., Jacob, D.J., 2011. All-time releases of mercury to the atmosphere from human activities. Environ. Sci Technol. 45 (24), 10485-10491.

Streets, D.G., Horowitz, H.M., Jacob, D.J., Lu, Z., Levin, L., Ter Schure, A.F.H., Sunderland, E.M., 2017. Total mercury released to the environment by human activities. Environ. Sci. Technol. 51, 5969-5977.

Subías, I., Fanlo, I., Billstrom, K., 2015. Ore-forming timing of polymetallic-fluorite low temperature veins from Central Pyrenees: a $\mathrm{Pb}, \mathrm{Nd}$ and $\mathrm{Sr}$ isotope perspective. Ore Geol. Rev. 70, 241-251.

Thevenon, F., Guédron, S., Chiaradia, M., Loizeau, J.-L., Poté, J., 2011. (Pre-) historic changes in natural and anthropogenic heavy metals deposition inferred from two contrasting Swiss Alpine lakes. Quat. Sci. Rev. 30, 224-233.

Tylmann, W., 2005. Lithological and geochemical record of anthropogenic changes in recent sediments of a small and shallow lake (Lake Pusty Staw, northern Poland) J. Paleolimnol. 33, 313-325.

Valero-Garcés, B.L., González-Sampériz, P., Navas, A., Machín, J., Mata, P., DelgadoHuertas, A., Bao, R., Moreno, A., Carrión, J.S., Schwalb, A., González-Barrios, A., 2006. Human impact since Medieval times and recent ecological Restorationin a Mediterranean Lake: the Laguna Zoñar, Southern Spain. J. Paleolimnol. 35, 441-465.

Valero-Garcés, B.L., Oliva-Urcia, B., Moreno Caballud, A., Rico, M.T., Mata-Campo, M.P., Salazar-Rincón, A., Rieradevall, M., García-Ruiz, J.M., Chueca Cía, J., GonzálezSampériz, P., Pérez-Sanz, A., Salabarnada, A., Pardo, A., Sancho Marcén, C., BarreiroLostres, F., Bartolomé, M., García-Prieto, E., Gil-Romera, G., López Merino, L.S. Sevilla-Callejo, M., Tarrats, P., 2013. Dinámica glacial, clima y vegetación en el Parque Nacional de Ordesa y Monte Perdido durante el Holoceno. In: O.A.P.N (Ed.), Proyectos de investigación en parques nacionales: 2009-2012, pp. 7-37.

Valero-Garcés, B., Morellón, M., Moreno, A., Corella, J.P., Martín-Puertas, C., Barreiro, F. Pérez, A., Giralt, S., Mata-Campo, M.P., 2014. Lacustrine carbonates of Iberian Karst Lakes: sources, processes and depositional environments. Sediment. Geol. 299, 1-29.

Vera, J.A., 2004. Geología de España. Sociedad Geológica de España e Instituto Geológico y Minero de España, Madrid (España) 84-7840-546-1 (890 pp).

von Gunten, H.R., Sturm, M., Moser, R.N., 1997. 200-year record of metals in Lake sediments and natural background concentrations. Environ. Sci. Technol. 31, 2193-2197.

von Storch, H., Costa-Cabral, M., Hagner, C., Feser, F., Pacyna, J., Pacyna, E., Kolb, S., 2003. Four decades of gasoline lead emissions and control policies in Europe: a retrospective assessment. Sci. Total Environ. 311, 151-176.

West, S., Charman, D.J., Grattan, J.P., Cherburkin, A.K., 1997. Heavy metals in Holocene peats from south West England: detecting mining impacts and atmospheric pollution. Water Air Soil Pollut. 100, 343-353.

Wirth, S.B., Gilli, A., Niemann, H., Dahl, T.W., Ravasi, D., Sax, N., Hamann, Y., Peduzzi, R. Peduzzi, S., Tonolla, M., Lehmann, M.F., Anselmetti, F.S., 2013. Combining sedimentological, trace metal (Mn, Mo) and molecular evidence for reconstructing past watercolumn redox conditions: the example of meromictic Lake Cadagno (Swiss Alps). Geochim. Cosmochim. Acta 120, 220-238.

Zhang, Y., Jacob, D.J., Horowitz, H.M., Chen, L., Amos, H.M., Krabbenhoft, D.P., Slemr, F., St. Louis, V.L., Sunderland, E.M., 2016. Observed decrease in atmospheric mercury explained by global decline in anthropogenic emissions. Proc. Natl. Acad. Sci. 113, 526-531. 